\title{
ROS-Responsive Chitosan Coated Magnetic Iron Oxide Nanoparticles as Potential Vehicles for Targeted Drug Delivery in Cancer Therapy
}

This article was published in the following Dove Press journal: International Journal of Nanomedicine

\author{
Srinivasan Ayyanaar' \\ Chandrasekar Balachandran ${ }^{2}$ \\ Rangaswamy Chinnabba \\ Bhaskar $^{3}$ \\ Mookkandi Palsamy Kesavan ${ }^{4}$ \\ Shin Aoki id ${ }^{2,5}$ \\ Ramachandran Palpandi Raja ${ }^{6}$ \\ Jegathalaprathaban Rajesh ${ }^{7}$ \\ Thomas J Webster (D) ${ }^{8}$ \\ Gurusamy Rajagopal' \\ 'PG and Research Department of \\ Chemistry, Chikkanna Government Arts \\ College, Tiruppur 64I 602, Tamilnadu, \\ India; ${ }^{2}$ Faculty of Pharmaceutical \\ Sciences, Tokyo University of Science, \\ Noda 278-8510, Japan; ${ }^{3}$ Department of \\ Chemistry, School of Advanced Sciences, \\ Vellore Institute of Technology, Vellore \\ 6320 I4, Tamil Nadu, India; ${ }^{4}$ Department \\ of Chemistry, Hajee Karutha Rowther \\ Howdia College, Uthamapalayam 625 \\ 533, Tamil Nadu, India; ${ }^{5}$ Research \\ Institute of Science and Technology, \\ Tokyo University of Science, Noda 278- \\ 8510, Japan; ${ }^{6}$ Centre for Biotechnology, \\ Anna University, Chennai 600 025, Tamil \\ $\mathrm{Nadu}$ India; ${ }^{7}$ Chemistry Research \\ Centre, Mohamed Sathak Engineering \\ College, Kilakarai 623806 , Tamil Nadu, \\ India; ${ }^{8}$ Department of Chemical \\ Engineering, Northeastern University, \\ Boston, MA 02II5, USA
}

Correspondence: Jegathalaprathaban Rajesh; Thomas J Webster Email mkuraji@gmail.com; th.webster@neu.edu
Background and Objective: Cancer cells accumulate high concentrations of reactive oxygen species as a result of their faster and uninhibited metabolic activity. Cancer chemotherapeutic agents release an excess of severe adverse reactions as a result of targeting normal cells. This demands an improvement in targeted drug-delivery systems to selectively discharge anticancer drugs in the vicinity of such highly metabolically and mitotically active cells.

Materials and Methods: Here, magnetic nanoparticles were synthesized by a traditional co-precipitation technique. $\mathrm{Fe}_{3} \mathrm{O}_{4} @ \mathrm{OA}-\mathrm{CS}-5$-FLU-NPs were synthesized by an easy and rapid in situ loading method. The proposed $\mathrm{Fe}_{3} \mathrm{O}_{4} @ \mathrm{OA}-\mathrm{CS}-5$-FLU-NPs were productively prepared as well as characterized by various spectroscopic and microscopic studies.

Results: The targeted drug release profile of the $\mathrm{Fe}_{3} \mathrm{O}_{4} @ \mathrm{OA}-\mathrm{CS}-5-\mathrm{FLU}-\mathrm{NPs}$ was studied in the presence of ROS including $\mathrm{H}_{2} \mathrm{O}_{2}$ and $\mathrm{pH}$ induction. The released product, $\mathrm{Fe}_{3} \mathrm{O}_{4} @ \mathrm{OA}-$ CS-5-FLU-NP, exhibited desirable levels of cytotoxicity and demonstrated morphological changes and inhibition of colony formation for A549 and HeLa S3 cancer cells. The IC50 values at 24 hours were 12.9 and $23 \mu \mathrm{g} / \mathrm{mL}$, respectively.

Conclusion: In summary, results from the MTT assay, fluorescence staining as well as colony formation assays, revealed that the $\mathrm{Fe}_{3} \mathrm{O}_{4} @ \mathrm{OA}-\mathrm{CS}-5$-FLU-NPs were active and safe for anticancer biomedical applications. In summary, the present investigation provides a powerful nanostructured based system for improved cancer theranostics that should be further studied.

Keywords: magnetic iron oxide nanoparticles, oleic acid, chitosan, 5-fluorouracil, cytotoxicity, targeted drug delivery

\section{Introduction}

Successful cancer therapy depends on the outcome of surgical resection of the affected tissue in combination with chemotherapy or radiation therapy. ${ }^{1-3}$ Although anticancer drugs are efficient at destroying tumor cells, they are potentially harmful as a result of their non-selectivity, which has limited their therapeutic use. ${ }^{4-6}$ In the last few decades, there have been more and more cases of nanoparticles (NPs), such as $\mathrm{Fe}_{3} \mathrm{O}_{4} \mathrm{NP}$, which have played a pivotal role in drug delivery specifically targeting cancer cells. ${ }^{7} \mathrm{Fe}_{3} \mathrm{O}_{4} \mathrm{NP}$ have gained great attention in various biomedical applications such as targeted delivery, localized hyperthermia treatment, as well as contrast agents for magnetic resonance imaging (MRI). ${ }^{8-10}$ As the $\mathrm{Fe}_{3} \mathrm{O}_{4} \mathrm{NP}$ are unstable in aqueous media, they cannot be used as drug carriers alone. In order to overcome this drawback, a coating is applied to employ lipids, proteins, carbohydrates, liposomes, synthetic and bio-degradable polymers. ${ }^{11-14}$ 
Chitosan has been proposed as a potential carrier for drugs and biological macromolecules ${ }^{15}$ with potential biomedical and pharmacological applications because of several attractive features such as low cost, safety, biodegradability and biocompatibility. ${ }^{16-18}$ Chitosan and its derivatives have many desirable biological and biochemical properties which could be attributed to reactive functional groups namely hydroxyl $(-\mathrm{OH})$ and amino $\left(-\mathrm{NH}_{2}\right)$ groups. On the other hand, chitosan is not suitable for binding to $\mathrm{Fe}_{3} \mathrm{O}_{4} \mathrm{NP}$ as the resulting magnetic compounds tend to form aggregates of polymer cross-linked complexes and polymer adsorbates. ${ }^{19,20}$

Many investigators have attempted to functionalize CS in order to bind onto $\mathrm{Fe}_{3} \mathrm{O}_{4} \mathrm{NP}$. Several reports highlight the internalization of some $\mathrm{Fe}_{3} \mathrm{O}_{4} \mathrm{NP}$ with an enhanced generation of reactive oxygen species (ROS). Enhanced ROS levels have demonstrated synergistic antitumor efficacy by stimulating mitochondria-meditated apoptosis. ${ }^{21-24}$

$\mathrm{Fe}_{3} \mathrm{O}_{4} \mathrm{NP}$ have been reported to up-regulate ROS including $\mathrm{H}_{2} \mathrm{O}_{2}$ which potentially play a key role in biomedical applications especially for targeted drug delivery. ${ }^{25}$ The assessment of anticancer drug-loaded nanoparticles and their effect on the induction of cell apoptosis, and the extent of the $\mathrm{Fe}_{3} \mathrm{O}_{4} \mathrm{NP}$ activated ROS-mediated mitochondrial apoptosis pathway, have not been experimentally investigated. 5-FLU is an anti-metabolite of the pyrimidine class, with a broad spectrum of activity and is quite effective in the chemotherapy of solid malignant tumors, such as that of the abdominal cavity, ovary, liver, brain, breast, etc., either alone or in combination. ${ }^{26,27}$ 5-FLU affects nucleoside uptake and can be incorporated into RNA as well as DNA, leading to cytotoxicity and cell damage. Oleic acid (OA) is a commonly used surfactant to stabilize magnetic nanoparticles synthesized by traditional co-precipitation methods, and some studies have proved that a strong chemical bond is formed between carboxylic acid and amorphous iron and amorphous iron oxide nanoparticles. OA possesses a non-polar hydrocarbon tail and a polar carboxylic acid head group. Carboxylate anions are known to coordinate with the surface of magnetite, presumably through a coordination of iron atoms with both of the carboxylate oxygens. Oleic acid and chitosan-based magnetic aggregates were investigated here as a controlled drug-delivery system capable of $\mathrm{pH}$ alteration and ROS release. ${ }^{28,29}$ They also exhibit enhanced levels of biocompatibility as well as desirable drug release characteristics. $^{30}$

Herein, we present the synthesis, characterization and evaluation of $\mathrm{Fe}_{3} \mathrm{O}_{4} @$ OA-CS-5-FLU-NPs as a combination drug carrier for the $\mathrm{pH}$-responsive release of 5-FLU delivery in A549 and HeLa S3 cell cultures and the resultant synergistic cytotoxicity of 5-FLU and ROS.

\section{Materials and Methods Chemicals}

Iron (II) tetrahydrate $\left(\mathrm{FeCl}_{2} \cdot 4 \mathrm{H}_{2} \mathrm{O}\right)$, iron (III) chloride hexahydrate $\left(\mathrm{FeCl}_{3} \cdot 6 \mathrm{H}_{2} \mathrm{O}\right)$, sodium hydroxide and oleic acid (OA) were purchased from Merck (India). Chitosan (CS) and 5-fluorouracil (5-FLU) were procured from Sigma-Aldrich. Milli-Q water and organic solvents of analytical grade were used in this study.

\section{Preparation of $\mathrm{Fe}_{3} \mathrm{O}_{4} @ \mathrm{OA} \mathrm{NPs}$}

$\mathrm{Fe}_{3} \mathrm{O}_{4}$ magnetic nanoparticles were synthesized by a chemical co-precipitation process. Concisely, $1.0 \mathrm{~g}$ of $\mathrm{FeCl}_{3} \cdot 6 \mathrm{H}_{2} \mathrm{O}$ and $0.5 \mathrm{~g}$ of $\mathrm{FeCl}_{2} \cdot 4 \mathrm{H}_{2} \mathrm{O}$ were dissolved in $50 \mathrm{~mL}$ of double-distilled water through a dynamic stirring process and the solution was allowed to reflux at $80{ }^{\circ} \mathrm{C}$. Then, the precipitant of the ammonia solution in $10 \mathrm{~mL}$ $\left(\mathrm{NH}_{4} \mathrm{OH}, 25\right.$ wt \%) was slowly dropped into the above mixture under vigorous stirring for $15 \mathrm{~min}^{31}$ the reason for using an ammonia solution was to increase the number and size of the nanoparticles. Ammonia could play a role not only in increasing the reaction rate but also in retarding the growth of the particles when used in different concentration ranges. Finally, the drop-wise addition of oleic acid $(3 \mathrm{~mL})$ into the above suspension led to an alteration at the surface of the $\mathrm{Fe}_{3} \mathrm{O}_{4} \mathrm{NP}^{27}$ This mixture was refluxed at $80{ }^{\circ} \mathrm{C}$ for 30 min to complete the formation of the $\mathrm{Fe}_{3} \mathrm{O}_{4}$ NP. Subsequently, the suspension was cooled down to room temperature and separated by a magnet, cleaned with distilled water and ethanol to remove the reactants and impurities. The final product of $\mathrm{Fe}_{3} \mathrm{O}_{4} @ \mathrm{OA}$ NP (oilbase surface) was desiccated at room temperature under a vacuum at $60{ }^{\circ} \mathrm{C}$ for $12 \mathrm{~h}$.

\section{Preparation of $\mathrm{Fe}_{3} \mathrm{O}_{4} @ O A-C S-N P s$}

Chitosan modified $\mathrm{Fe}_{3} \mathrm{O}_{4} \mathrm{NPs}$ were synthesized by the coprecipitation of $\mathrm{Fe}^{2+}$ and $\mathrm{Fe}^{3+}$ salts in the presence of chitosan. ${ }^{32}$ Chitosan $(0.125 \mathrm{~g})$ was solidified in $30 \mathrm{~mL}$ of $1 \%$ acetic acid and the $\mathrm{pH}$ was tuned to 4.8 by adding 10 $\mathrm{M} \mathrm{NaOH}$. The $\mathrm{Fe}_{3} \mathrm{O}_{4} @$ OA NPs $(1 \mathrm{~g})$ were added to $30 \mathrm{~mL}$ of a chitosan solution while stirring under an inert atmosphere at $50{ }^{\circ} \mathrm{C}$. Then, $30 \mathrm{~mL}$ of an aqueous ammonia solution $(25 \%)$ was gently added to the above mixture to yield small nanoparticles. The resulting mixture was further stirred for 
30 min. The colloidal $\mathrm{Fe}_{3} \mathrm{O}_{4} @$ OA-CS-NP was continuously washed with distilled water and separated by magnetic decantation repeatedly.

\section{Preparation of $\mathrm{Fe}_{3} \mathrm{O}_{4} @ \mathrm{OA}-\mathrm{CS}-5-\mathrm{FLU}-\mathrm{NPs}$} $\mathrm{Fe}_{3} \mathrm{O}_{4} @ \mathrm{OA}-\mathrm{CS}-5$-FLU-NPs were prepared based on an in situ filling process as shown in Figure 1. For the loading method, $\mathrm{Fe}_{3} \mathrm{O}_{4} @$ OA-CS-NPs $(100 \mathrm{mg})$ were mixed with 5-FLU and stirred at room temperature for $48 \mathrm{~h}$. The negatively charged 5-FLU molecules electrostatically interacted with positively charged CS molecules for the formation of $\mathrm{Fe}_{3} \mathrm{O}_{4} @$ OA-CS-5-FLU-NPs. Chitosan is a hydrophilic cationic polymer used to prepare nanoparticles by means of electrostatic interactions. 5-fluorouracil (5-FU) is a hydrophilic drug. Two ionic interactions exist in the reaction process: an intense electrostatic interaction between the positively charged amino group of CS and the negatively charged 5-FLU solution. The suspension was carefully collected using a magnet and washed with an abundant amount of water and ethanol to remove the unreacted particles. Finally, the $\mathrm{Fe}_{3} \mathrm{O}_{4} @$ OA-CS-5-FLU-NP powder was obtained after drying under vacuum pressure. ${ }^{33}$

\section{Characterization of $\mathrm{Fe}_{3} \mathrm{O}_{4} @ \mathrm{OA}-\mathrm{CS}$ - 5-FLU-NPs}

Powder X-ray diffraction (XRD) of $\mathrm{Fe}_{3} \mathrm{O}_{4} @ \mathrm{OA}-\mathrm{CS}$ -5-FLU-NP was analyzed by a X'Perto Pro, PANalytical $\mathrm{X}$-ray diffractometer using a $\mathrm{CuK} \alpha$ energy source $(\lambda=1.5406 \AA)$. The $\mathrm{Fe}_{3} \mathrm{O}_{4} @$ OA-CS-5-FLU-NPs were further characterized using a Perkin Elmer Fourier transform-infra red (FT-IR) spectrophotometer. Transmission electron microscopy (TEM) and scanning electron microscopy (SEM) micrographs of the $\mathrm{Fe}_{3} \mathrm{O}_{4} @ \mathrm{OA}-\mathrm{CS}-5-\mathrm{FLU}-$ NP were collected using a JSM-6390LVJEOL (Japan) to analyze surface morphology. The magnetic properties of the $\mathrm{Fe}_{3} \mathrm{O}_{4} @ \mathrm{OA}-\mathrm{CS}-5$-FLU-NPs were studied using a Lakeshore 7404-vibrating sample magnetometer (VSM) at room temperature. Thermogravimetric analysis (TGA) was done on a SDT Q600 (USA) TA instrument.

\section{Estimation of Drug Encapsulation Efficiency of $\mathrm{Fe}_{3} \mathrm{O}_{4} @ \mathrm{OA}-\mathrm{CS}-5-\mathrm{FLU}-\mathrm{NPs}$}

The concentration of the $\mathrm{Fe}_{3} \mathrm{O}_{4} @$ OA-CS-5-FLU-NP was estimated by UV-Vis spectrophotometry. 10 milligrams of $\mathrm{Fe}_{3} \mathrm{O}_{4} @$ OA-CS-5-FLU-NP dissolved in $1 \mathrm{~mL}$ of DCM (dichloromethane, to allow for a more extensive and increased drug-loading into the interior of nanoparticle) was taken in a closed glass tube and $10 \mathrm{~mL}$ of phosphate buffer ( $\mathrm{pH}$ 7.4) was added to it (the total volume of the releasing medium was maintained as constant by adding an equal volume of fresh buffer solution). The mixture was stirred for $2 \mathrm{~h}$ at room temperature. The mixture was centrifuged at $6000 \mathrm{rpm}$ for $10 \mathrm{~min}$ after the slow evaporation of DCM. The buffer solution was separated and the amount of 5-FLU in the buffer solution was estimated by spectrophotometry at $270 \mathrm{~nm}$. The following equations were used to determine drug content and encapsulation efficiency:

$$
\text { Drug content }=\frac{\begin{array}{l}
\text { Weight of encapsulated } \\
\text { drug in nanoparticles }
\end{array}}{\text { Weight of nanoparticles }} \times 100
$$

$$
\text { Encapsulation efficiency }=\frac{\begin{array}{l}
\text { Weight of } \\
\text { encapsulated drug } \\
\text { in nanoparticles }
\end{array}}{\begin{array}{l}
\text { Weight of initial } \\
\text { loading of drug }
\end{array}} \times 100 \%
$$

\section{In vitro Drug Release Studies}

The drug release characteristics of the arranged $\mathrm{Fe}_{3} \mathrm{O}_{4}$ (a) OA-CS-5-FLU-NP was determined as follows: $100 \mathrm{mg}$ of the each $\mathrm{Fe}_{3} \mathrm{O}_{4} @ \mathrm{OA}$-CS-5-FLU-NP were placed in four individual glass beakers in $5 \mathrm{~mL}$ each containing phosphate buffer solutions of $\mathrm{pH} 7.4$ and 5.2, respectively, along with $133 \mu \mathrm{M} \mathrm{H}_{2} \mathrm{O}_{2}$ placed on a mechanical shaker. Samples were collected $(1 \mathrm{~mL})$ at regular time intervals, and the concentration of 5-FLU released from the $\mathrm{Fe}_{3} \mathrm{O}_{4}$ (a) OA-CS-5-FLU-NP was determined by measuring the absorbance at $270 \mathrm{~nm}$. The drug release efficiency of $\mathrm{Fe}_{3} \mathrm{O}_{4} @$ OA-CS-5-FLU-NP was calculated using the following equation:

$$
\text { Drug releasing efficiency }(\%)=\frac{C_{t}}{C_{0}-C_{t}} \times 100
$$

where $C_{t}$ is the concentration of 5-FLU released from $\mathrm{Fe}_{3} \mathrm{O}_{4} @$ OA-CS-5-FLU-NP at time " $t$ " and $C_{0}$ is the initial concentration of the $\mathrm{Fe}_{3} \mathrm{O}_{4} @$ OA-CS-5-FLU-NP.

\section{In vitro Cytotoxicity Studies MTT Cytotoxic Assay}

A549, HeLa S3, MCF-7 and IMR-90 cells were purchased from ATCC, Manassas, VA, USA. A549, HeLa S3, MCF-7 and IMR-90 cell lines were cultured in DMEM medium (Dulbecco's Modified Eagle's Medium) and incubated at $37{ }^{\circ} \mathrm{C}$ with $5 \% \mathrm{CO}_{2}$. Cells were seeded overnight onto 96well plates at a density of 20,000 cells per well. After 


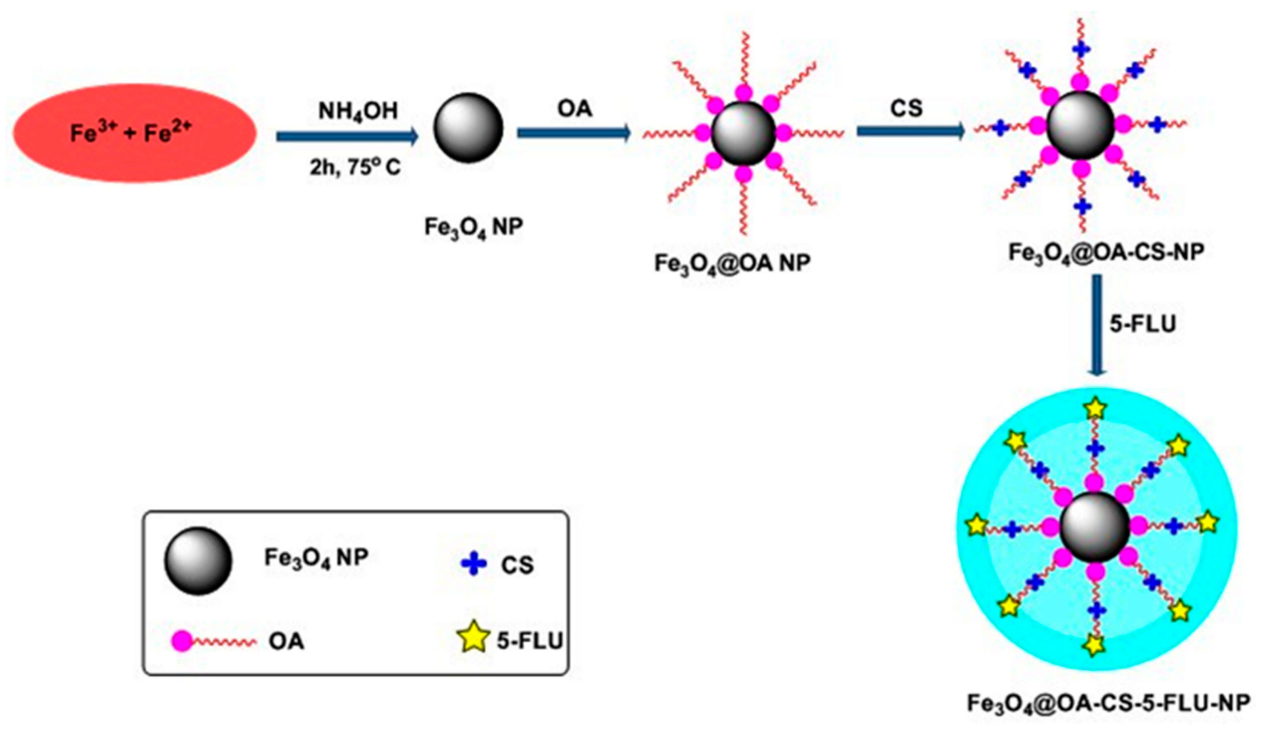

Figure I Schematic illustration of the preparation of $\mathrm{Fe}_{3} \mathrm{O}_{4} @ O A-C S-5-F L U-N P$.

completion of the incubation period, the fresh medium containing blank nanoparticles or drug encapsulated nanoparticles were added to each well. Over a period of time, $10 \mu \mathrm{L}$ of the (3-(4,5-dimethylthiazol-2-yl)-2,5-diphenyltetrazolium bromide) MTT solution $\left(5 \mathrm{mg} \mathrm{mL}^{-1}\right.$ ) was added to each well, and then plates were further incubated for 4 h. Then, $100 \mu \mathrm{L}$ of a formazan lysis solution (10\% SDS in $0.1 \mathrm{~N} \mathrm{HCl}$ ) was added to each well. The absorbance was measured at a wavelength of $570 \mathrm{~nm}$ using a microplate reader (BIO-RAD).

\section{AO/EB Staining Assay}

$\mathrm{AO} / \mathrm{EB}$ fluorescence staining was performed to detect the morphological changes in apoptosis in A549 and HeLa S3 cells. Cells $\left(1 \times 10^{5}\right)$ maintained in DMEM for $24 \mathrm{~h}$ were exposed to $15 \mu \mathrm{g} / \mathrm{mL}\left(\mathrm{Fe}_{3} \mathrm{O}_{4} @\right.$ OA-CS-5-FLU-NP) at 37 ${ }^{\circ} \mathrm{C}$ and $5 \% \mathrm{CO}_{2}$. Then, $10 \mu \mathrm{L}$ of a AO/EB dye was added to each well and further incubated for 15 min under dark conditions. The cells under fluorescence images were captured on a Biorevo, BZ-9000, Keyence (20x) fluorescence microscope system.

\section{Colony Formation Assay}

A549 and HeLa S3 $\left(5 \times 10^{3}\right.$ cells/well) cell lines were kept at $37^{\circ} \mathrm{C}$ in a humidified atmosphere containing $5 \% \mathrm{CO}_{2}$. Cells were cultured in DMEM medium and the A549 and HeLa S3 cells were washed twice with PBS buffer and incubated with various concentrations of MMS. After a period of time (10 days), the wells were washed with deionized water and stained with a crystal violet solution for $15 \mathrm{~min}$. The obtained results were calculated by Image J software using colony area.

\section{Statistical Analysis}

Tests were completed at least three times each and the data were characterized as the average and standard deviation (mean $\pm \mathrm{SD}$ ) of three independent experiments. One-way ANOVA analysis was used for comparing between groups and $\mathrm{P}<0.05$ was considered a statistically significant difference.

\section{Results and Discussion Morphology and FTIR Analyses of $\mathrm{Fe}_{3} \mathrm{O}_{4}$ @OA-CS-5-FLU-NPs}

The surface morphology of the $\mathrm{Fe}_{3} \mathrm{O}_{4} @ \mathrm{OA}-\mathrm{CS}-5-\mathrm{FLU}-$ NPs was analyzed through scanning electron micrographs (SEM). As depicted in Figure 2A, the nanoparticles appeared to be spherically-shaped with an average size of $1.5 \mu \mathrm{m}$ and a smooth outer surface. Under an external magnetic field, $\mathrm{Fe}_{3} \mathrm{O}_{4} @$ OA-CS-5-FLU-NP with a diameter of $50 \mathrm{~nm}$ can be selectively targeted to affected tissues.

The corresponding energy dispersive $\mathrm{X}$-ray spectrum (EDX) of $\mathrm{Fe}_{3} \mathrm{O}_{4} @$ OA-CS-5-FLU-NP is shown in Figure 2B. The characteristic peaks of carbon, nitrogen, oxygen and iron are presented by $\mathrm{CS}$ and 5-FLU. Furthermore, the metallic iron peaks show the existence of $\mathrm{Fe}_{3} \mathrm{O}_{4}$ NPs in the $\mathrm{Fe}_{3} \mathrm{O}_{4} @$ OA-CS-5-FLU-NPs. 


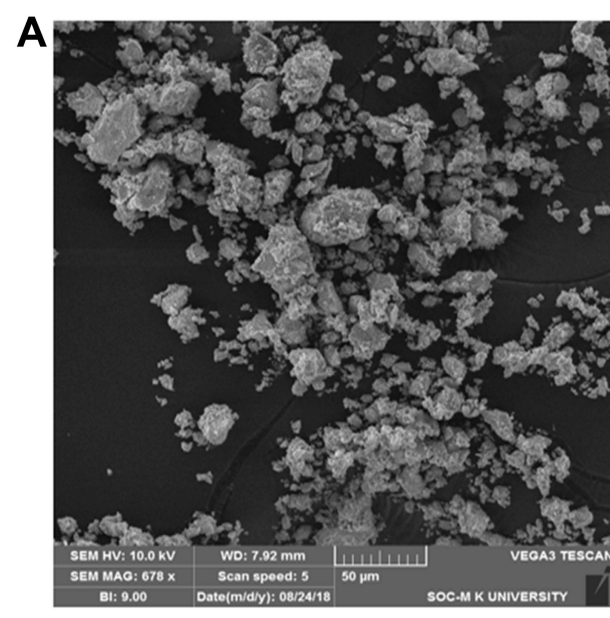

Figure 2 (A) SEM image and (B) EDX spectrum of $\mathrm{Fe}_{3} \mathrm{O}_{4} @ O A-C S-5-F L U-N P$.

Due to the drying effects, aggregated SEM images for $\mathrm{Fe}_{3} \mathrm{O}_{4} @$ OA-CS-5-FLU-NPs were achieved. EDX results clearly showed that CS and 5-FLU were loaded on the surface of the $\mathrm{Fe}_{3} \mathrm{O}_{4} \mathrm{NPs}$. This is only supporting evidence. Meanwhile, the presence of CS and 5-FLU was further confirmed by FT-IR analysis (Figure 3). The FT-IR spectrum of $\mathrm{Fe}_{3} \mathrm{O}_{4} \mathrm{NPs}$ showed a band at $580 \mathrm{~cm}^{-1}$ corresponding to $\mathrm{Fe}-\mathrm{O}$ stretching. The characteristic $\mathrm{O}-\mathrm{H}$ stretching of the

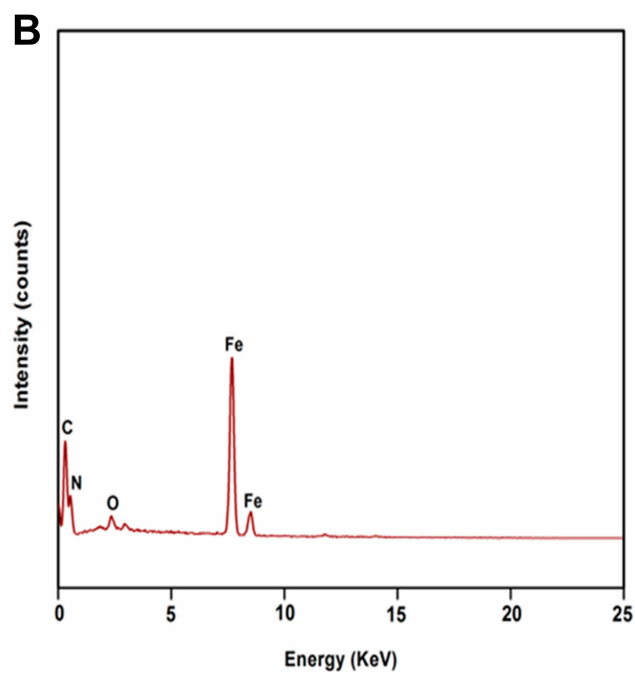

hydroxyl group present in the oleic acid was observed at $3405 \mathrm{~cm}^{-1}$. The peaks observed at 1395, 1612 and $2920 \mathrm{~cm}^{-1}$ corresponded to $\mathrm{C}-\mathrm{O}, \mathrm{C}=\mathrm{O}$ and $\mathrm{C}-\mathrm{H}$ stretching vibrations, respectively. ${ }^{34}$ The FT-IR spectrum of CS showed a band at $3430 \mathrm{~cm}^{-1}$ for the $\mathrm{O}-\mathrm{H}$ stretching vibration. Further, the peaks corresponding to $1660 \mathrm{~cm}^{-1}(\mathrm{C}=\mathrm{O}$ at amide I), $1660 \mathrm{~cm}^{-1}$ (N-H at amide II) and $885 \mathrm{~cm}^{-1}$ (C-N at amide III) correspond to $-\mathrm{NH}$ bending vibrations. 5-FLU

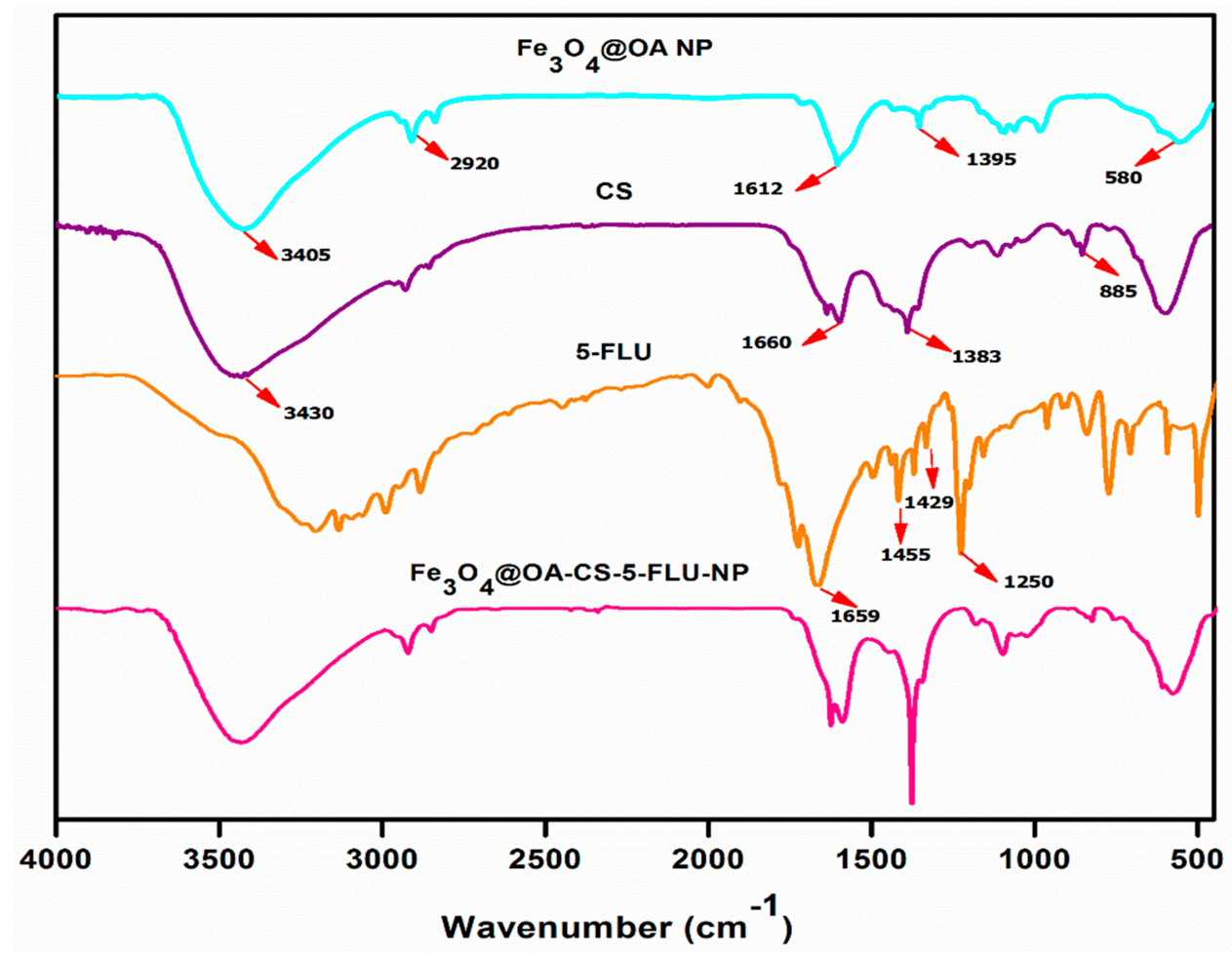

Figure 3 FT-IR spectrum of $\mathrm{Fe}_{3} \mathrm{O}_{4} \mathrm{NP}, \mathrm{Fe}_{3} \mathrm{O}_{4} @ \mathrm{OA} \mathrm{NP}, \mathrm{CS}, 5-\mathrm{FLU}$ and $\mathrm{Fe}_{3} \mathrm{O}_{4} @$ OA-CS-5-FLU-NP. 

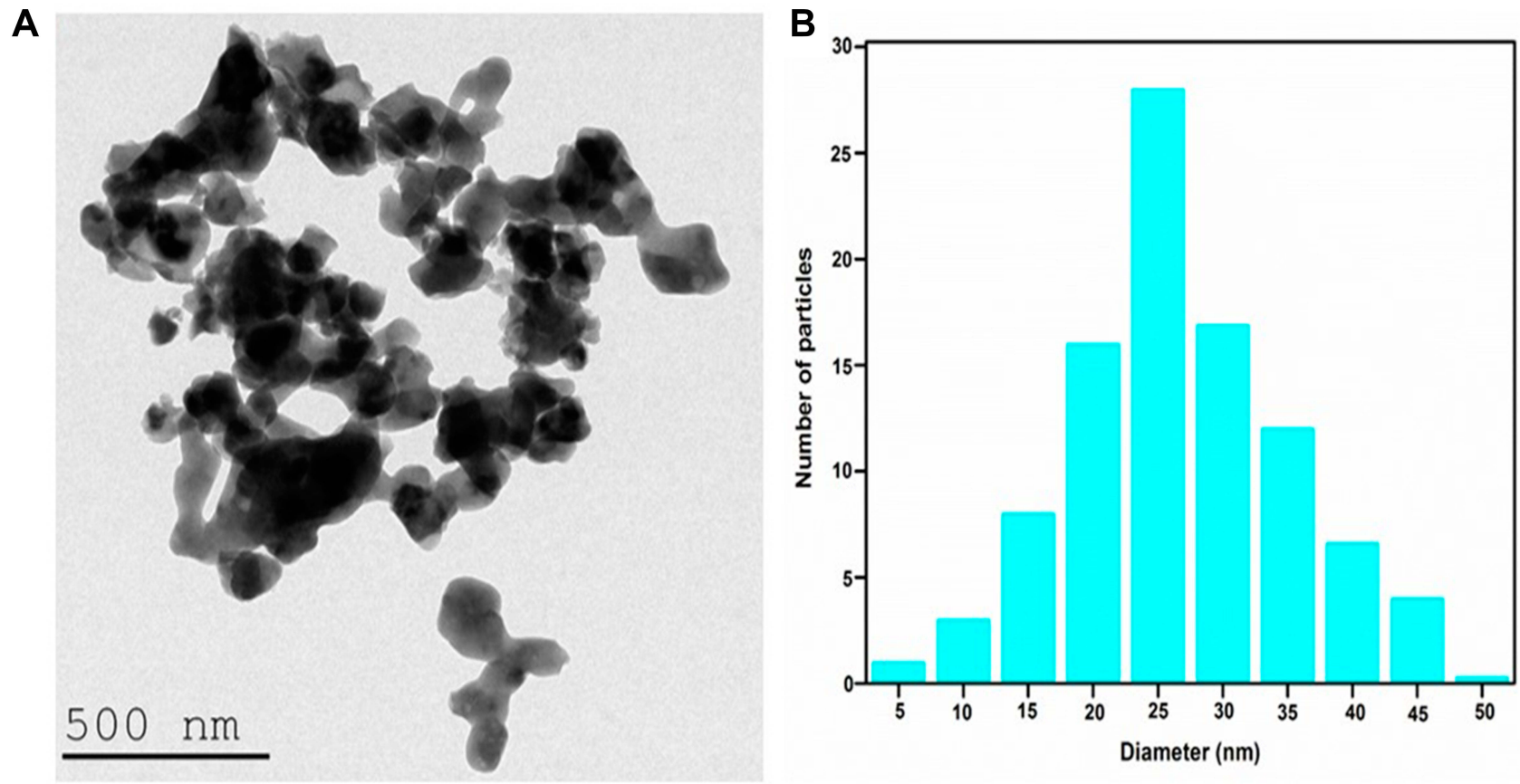

Figure 4 (A) TEM image and (B) Particle size distribution of $\mathrm{Fe}_{3} \mathrm{O}_{4} @ \mathrm{OA}-\mathrm{CS}-5-\mathrm{FLU}-\mathrm{NP}$ at $37{ }^{\circ} \mathrm{C}$ measured by dynamic light scattering.

displayed a broad vibrational band which appeared around $1659 \mathrm{~cm}^{-1}$ for the overlapping of peaks corresponding to the $\mathrm{C}=\mathrm{C}, \mathrm{C}=\mathrm{N}$, and $\mathrm{C}=\mathrm{O}$ groups. The strong absorption bands observed at 1250 as well as $1429-1455 \mathrm{~cm}^{-1}$ can be assigned to the vibration of the multi-substituted pyrimidine compound and C-O, respectively. The FT-IR spectrum of $\mathrm{Fe}_{3} \mathrm{O}_{4} @ \mathrm{OA}-\mathrm{CS}-5-\mathrm{FLU}-\mathrm{NP}$ presented all the characteristic peaks of its components, such as $\mathrm{Fe}_{3} \mathrm{O}_{4} @ \mathrm{OAN} \mathrm{NP}, \mathrm{CS}$, and 5-FLU and proved the successful formation of $\mathrm{Fe}_{3} \mathrm{O}_{4} @ \mathrm{OA}$ CS-5-FLU-NP. ${ }^{35}$

\section{Morphology and TEM Analyses of $\mathrm{Fe}_{3} \mathrm{O}_{4}$ @OA-CS-5-FLU-NPs}

The morphology of the synthesized $\mathrm{Fe}_{3} \mathrm{O}_{4} @$ OA-CS-5-FLUNPs was characterized at $37^{\circ} \mathrm{C}$ using TEM analysis. The TEM image shown in Figure 4 for $\mathrm{Fe}_{3} \mathrm{O}_{4} @$ OA-CS-5-FLUNPs revealed that the magnetic nanoparticles agglomerated, and the average particle size was about $20-35 \mathrm{~nm}$ as measured by DLS. Thus, the polymer on the nanoparticles did not lead to aggregation between the particles.

\section{X-Ray Diffraction Analysis of $\mathrm{Fe}_{3} \mathrm{O}_{4}$ @OA-CS-5-FLU-NP}

The crystalline nature of the $\mathrm{Fe}_{3} \mathrm{O}_{4} \mathrm{NPs}, \mathrm{Fe}_{3} \mathrm{O}_{4} @ \mathrm{OA}$ NPs and $\mathrm{Fe}_{3} \mathrm{O}_{4} @ \mathrm{OA}-\mathrm{CS}-5-\mathrm{FLU}-\mathrm{NPs}$ was analyzed by $\mathrm{X}$-ray diffraction (Figure 5). Diffraction peaks were

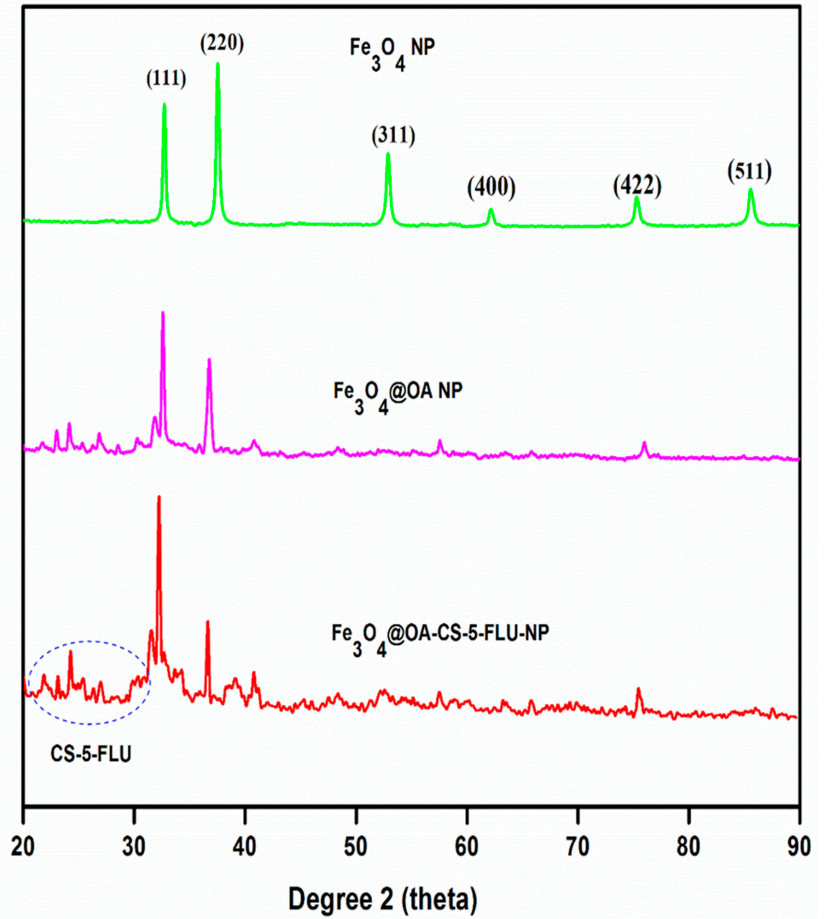

Figure 5 XRD patterns of $\mathrm{Fe}_{3} \mathrm{O}_{4} \mathrm{NP}, \mathrm{Fe}_{3} \mathrm{O}_{4} @ O A N P$ and $\mathrm{Fe}_{3} \mathrm{O}_{4} @ O A-C S-5-F L U-N P$.

observed at $2 \theta$ values of $31.25^{\circ}, 33.46^{\circ}, 52.14^{\circ}$, $61.75^{\circ}, 75.42^{\circ}$ and $86.15^{\circ}$ due to its crystalline nature. The $\mathrm{Fe}_{3} \mathrm{O}_{4} @ \mathrm{OA}$ XRD pattern contained a slight semicrystalline peak due to the surface attached oleate moiety. The respective peaks of the planes (311), (400), and 
(511) were suppressed in $\mathrm{Fe}_{3} \mathrm{O}_{4} @ \mathrm{OA}-\mathrm{CS}-5$-FLU due to the surface decorated OA, CS and 5-FLU. The crystalline nature of $\mathrm{Fe}_{3} \mathrm{O}_{4} \mathrm{NP}$ was retained even after loading of OA on the surface of the $\mathrm{Fe}_{3} \mathrm{O}_{4}$ NPs. It is suggested that the $\mathrm{Fe}_{3} \mathrm{O}_{4} \mathrm{NPs}$ in situ formed between the CS5-FLU and the peak at the range of $2 \theta=21.33-24.27^{\circ}$ was assigned as the semi-crystalline response of CS5-FLU. ${ }^{36,37}$ The decoration of CS and 5-FLU on the surface of $\mathrm{Fe}_{3} \mathrm{O}_{4} @ \mathrm{OA}$ NPs increased in intensity for the semi-crystalline peaks and this confirmed the successful formation of the $\mathrm{Fe}_{3} \mathrm{O}_{4} @ \mathrm{OA}-\mathrm{CS}-5$-FLU-NPs.

\section{Thermal Stability}

TGA analysis of the $\mathrm{Fe}_{3} \mathrm{O}_{4} @$ OA-CS-5-FLU-NPs was performed under inert conditions. Figure 6 shows the TGA curves of the $\mathrm{Fe}_{3} \mathrm{O}_{4} @ \mathrm{OA}$ NPs and $\mathrm{Fe}_{3} \mathrm{O}_{4} @ \mathrm{OA}-\mathrm{CS}$ -5-FLU-NPs. The primary weight loss up to $100{ }^{\circ} \mathrm{C}$ might be the adsorbed water in those test mixtures. The TGA data showed the weight loss in the $\mathrm{Fe}_{3} \mathrm{O}_{4} @ \mathrm{OA}$ NPs and a considerable decomposition was observed around 200-350 ${ }^{\circ} \mathrm{C}$ due to the loss of surface water. The obtained decomposition $\sim 370-450^{\circ} \mathrm{C}$ matches the charged anticancer drug 5-FLU. The TGA of $\mathrm{Fe}_{3} \mathrm{O}_{4} @ \mathrm{OA}$ had a weight loss curve in the range of $410-520{ }^{\circ} \mathrm{C}$ due to the decomposition of the coated OA. ${ }^{38}$ These results indicated the reducing thermal strength of $\mathrm{Fe}_{3} \mathrm{O}_{4} @ \mathrm{OA}$ NPs after the

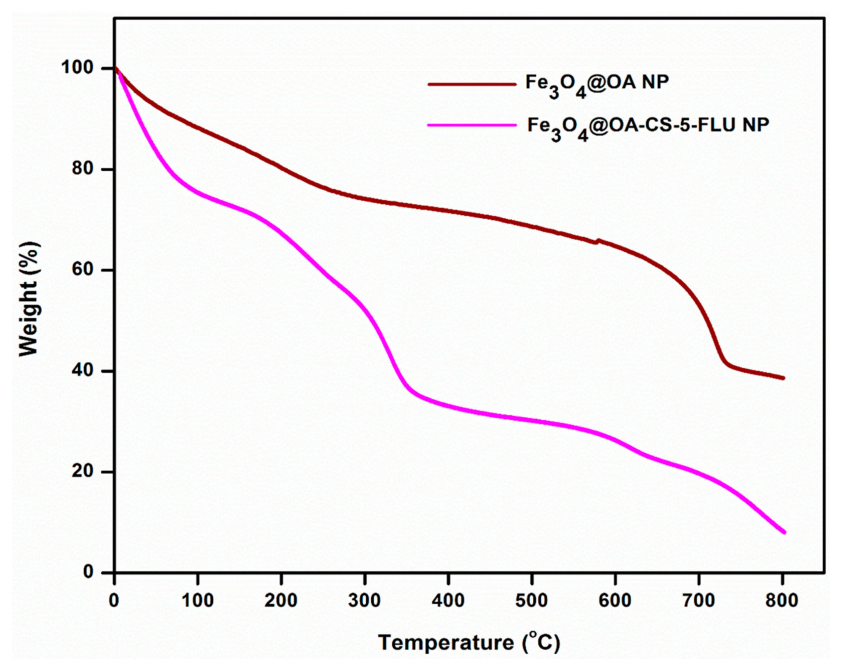

Figure 6 TGA curves of the $\mathrm{Fe}_{3} \mathrm{O}_{4} @ \mathrm{OA} \mathrm{NP}$ and $\mathrm{Fe}_{3} \mathrm{O}_{4} @ \mathrm{OA}-\mathrm{CS}-5-\mathrm{FLU}-\mathrm{NP}$

addition of the desired compositions of CS and 5-FLU in the $\mathrm{Fe}_{3} \mathrm{O}_{4} @$ OA-CS-5-FLU-NPs.

\section{Magnetic Characteristic Analysis of $\mathrm{Fe}_{3} \mathrm{O}_{4}$ @OA-CS-5-FLU-NPs}

The magnetic properties of the $\mathrm{Fe}_{3} \mathrm{O}_{4} @ \mathrm{OA}$ NPs and $\mathrm{Fe}_{3} \mathrm{O}_{4}$ (a) OA-CS-5-FLU-NPs were studied by VSM at room temperature and the data is presented in Figure 7A. The higher saturation magnetization value of $73.25 \mathrm{emu} / \mathrm{g}$ was obtained

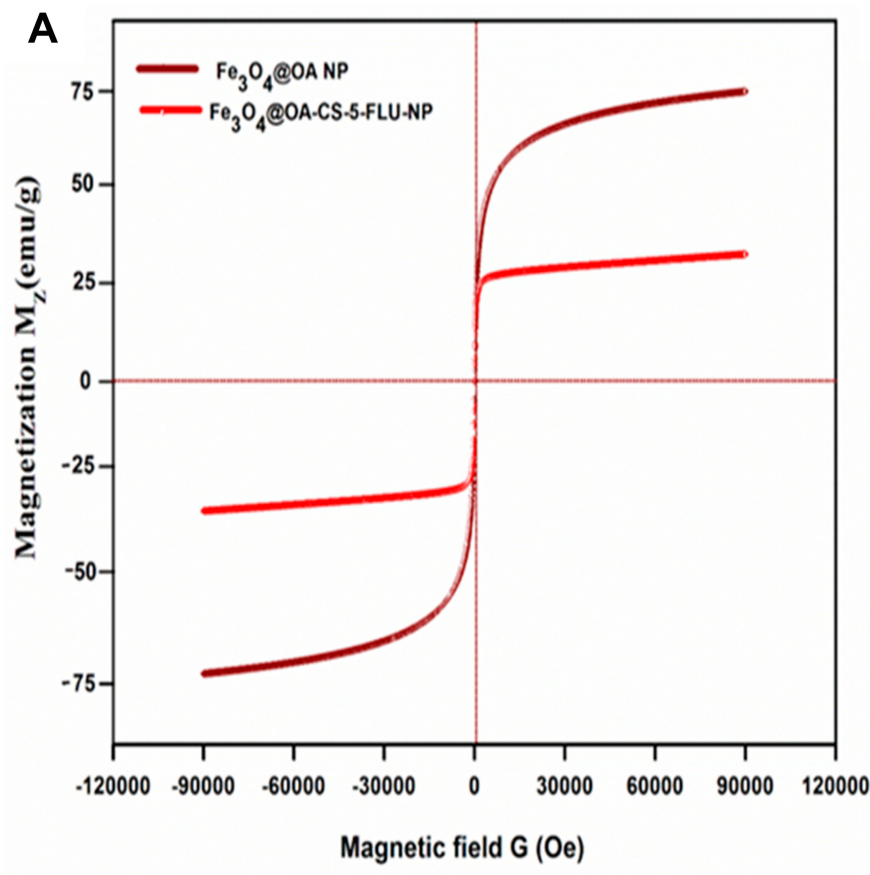

B

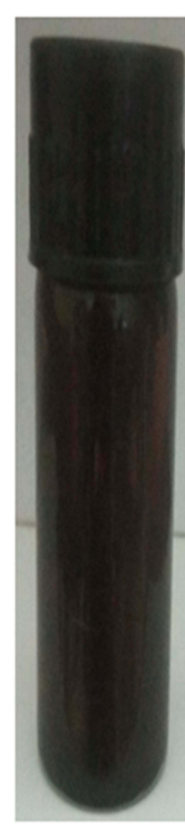

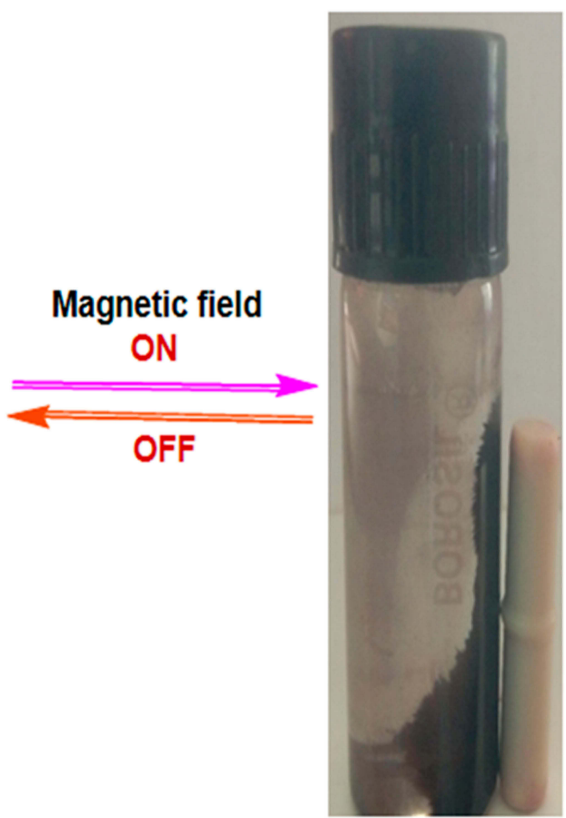

Figure 7 (A) Room temperature hysteresis curves of magnetite with $\mathrm{Fe}_{3} \mathrm{O}_{4} @ \mathrm{OA} N \mathrm{NP}$ and $\mathrm{Fe}_{3} \mathrm{O}_{4} @ \mathrm{OA}-\mathrm{CS}-5-\mathrm{FLU}-\mathrm{NP}$ and (B) Magnetic field responsive behavior of Fe $\mathrm{O}_{4}$ @OA-CS-5-FLU-NP. 

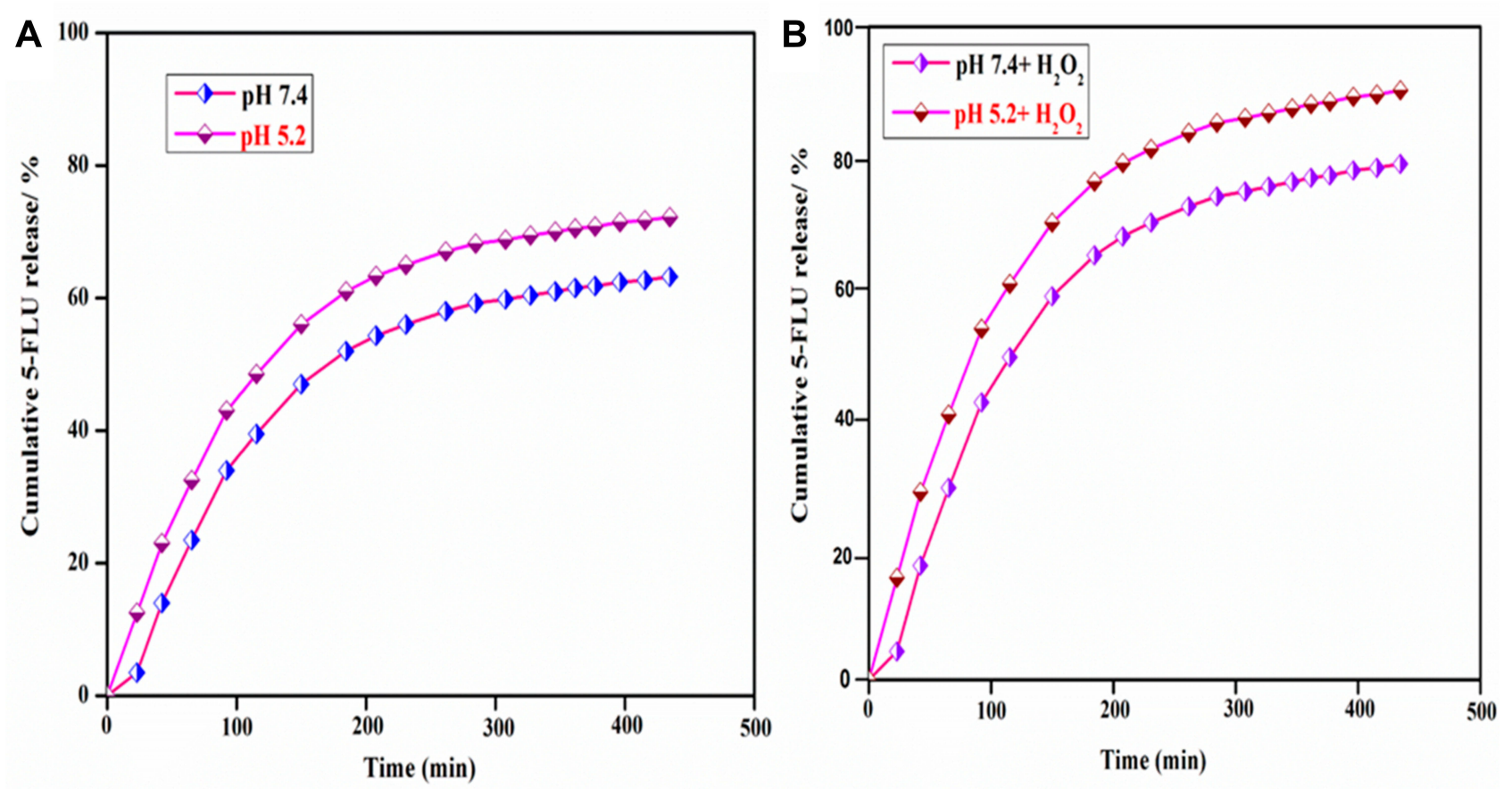

Figure 8 (A) Release curves at pH 7.4 and pH 5.2 in PBS containing $\mathrm{Fe}_{3} \mathrm{O}_{4} @ \mathrm{OA}-\mathrm{CS}-5$-FLU-NPs. (B) 5-FLU release profile at pH $7.4\left(\mathrm{H}_{2} \mathrm{O}_{2}\right)$ and pH $5.2\left(\mathrm{H}_{2} \mathrm{O}_{2}\right)$ in $\mathrm{PBS}$ containing $\mathrm{Fe}_{3} \mathrm{O}_{4} @ \mathrm{OA}-\mathrm{CS}-5-\mathrm{FLU}-\mathrm{NP}$.

for the $\mathrm{Fe}_{3} \mathrm{O}_{4} @ \mathrm{OA}$ NPs. However, a lower saturation magnetization of $30.21 \mathrm{emu} / \mathrm{g}$ was found for the $\mathrm{Fe}_{3} \mathrm{O}_{4} @ \mathrm{OA}-\mathrm{CS}$ -5-FLU-NPs. Hence, the gained magnetic targeted drugdelivery for these NPs has potential for broad biomedical applications. The lower value of the saturation magnetization is due to the smaller size of the nanoparticles and the low saturation magnetization of the $\mathrm{Fe}_{3} \mathrm{O}_{4} @ \mathrm{OA}-\mathrm{CS}-5$-FLU$\mathrm{NP}$ composite may be attributed to the presence of a thick polymeric layer of CS and 5-FLU on the $\mathrm{Fe}_{3} \mathrm{O}_{4} @ \mathrm{OA} \mathrm{NPs.}{ }^{39}$ The $\mathrm{Fe}_{3} \mathrm{O}_{4} @$ OA-CS-5-FLU-NPs also retained superior paramagnetic properties at room temperature which is useful in a drug-releasing system. As they do not retain magnetization before and after exposure to an external localized magnetic field, this reduces the probability of particle aggregation due to magnetic dipole attraction. The higher magnetization of the $\mathrm{Fe}_{3} \mathrm{O}_{4} @ \mathrm{OA}-\mathrm{CS}-5$-FLU-NPs is useful for magnetically targeted drug-delivery systems. Hence, the magnetic performances of $\mathrm{Fe}_{3} \mathrm{O}_{4} @$ OA-CS-5-FLU-NPs (Figure 7B) afford good targeted ability for therapeutic applications.

\section{In vitro Drug Release Studies}

Accordingly, these nanoparticles might exhibit cytotoxic activity as carrier molecules consisting of OA along with the drug which could be absorbed by simple diffusion. The in vitro release of 5-FLU from the $\mathrm{Fe}_{3} \mathrm{O}_{4} @ \mathrm{OA}-\mathrm{CS}-5$-FLU-
NP aggregates was studied in PBS at different $\mathrm{pH}$ values as illustrated in Figure 8A. At the physiological $\mathrm{pH}$ of 7.4, 5-FLU uptake (as determined was adsorbed on the $\mathrm{Fe}_{3} \mathrm{O}_{4}$ (a) OA-CS-5-FLU-NPs) was released very slowly and the amount of the released 5-FLU presented as a weight

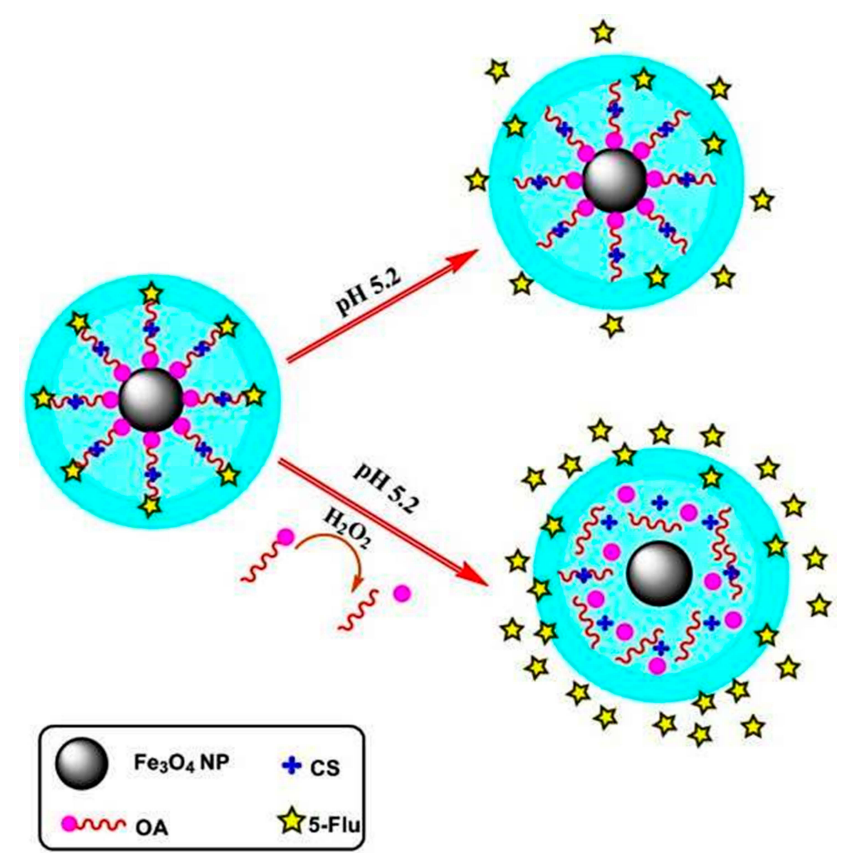

Figure 9 Schematic representation of ROS activated 5-FLU release from $\mathrm{Fe}_{3} \mathrm{O}_{4}$ @OA-CS-5-FLU-NP in a cancerous cell mimicking PH (5.2) medium. 


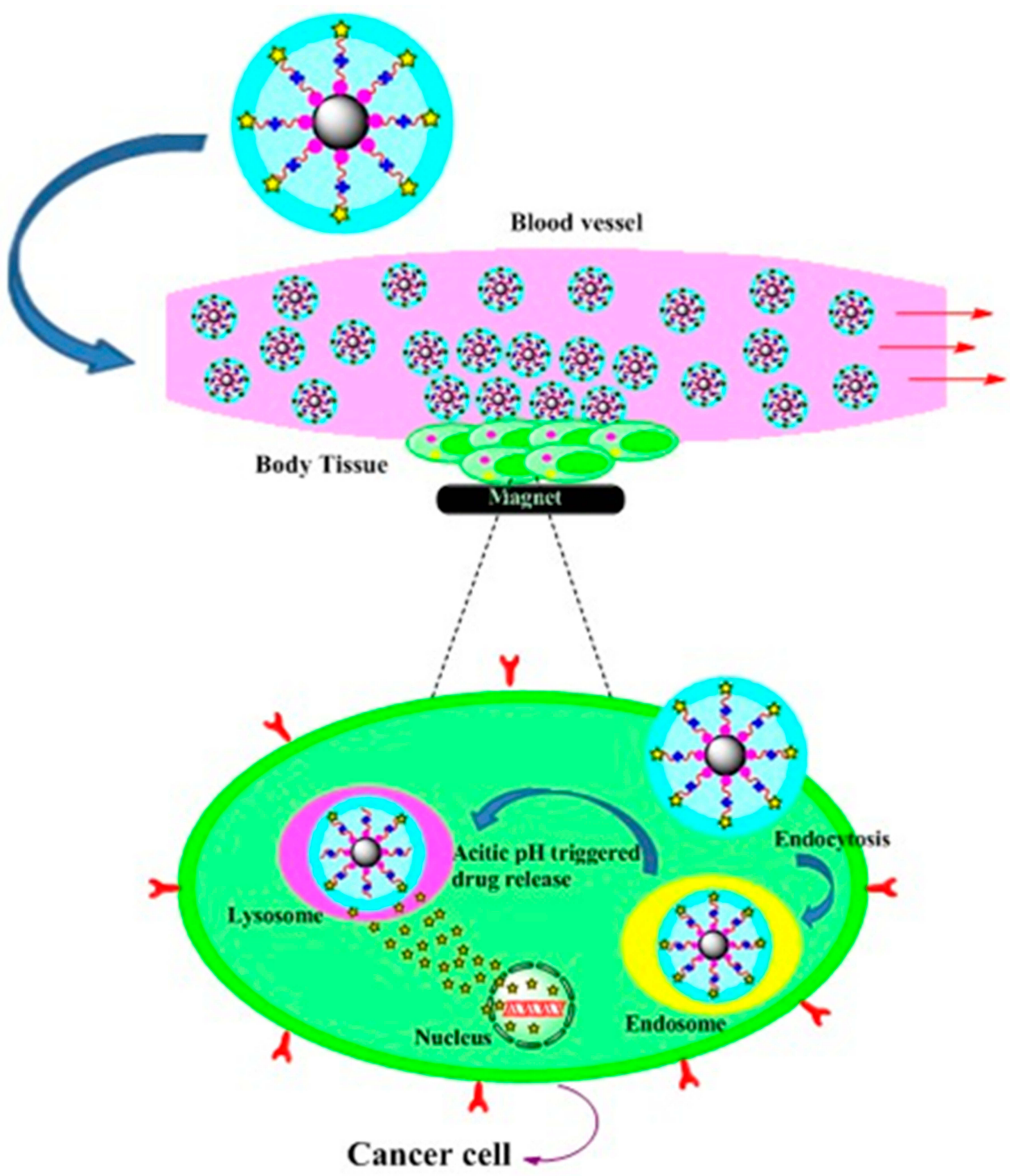

Figure 10 Schematic illustration showing the magnetically targeted pH $5.2\left(\mathrm{H}_{2} \mathrm{O}_{2}\right)$ in PBS as a responsive 5-FLU release process from the Fe $3 \mathrm{O}_{4} @ \mathrm{OA}-\mathrm{CS}-5$-FLU-NP.

percentage of the total 5-FLU adsorbed, was only about $62 \%$ over a period of $500 \mathrm{~min}$. In contrast, in PBS at pH 5.2, to mimic the intracellular conditions of cancer cells, the release rate of 5-FLU from the $\mathrm{Fe}_{3} \mathrm{O}_{4} @$ OA-CS-5-FLU-NP was much faster and the highest release of 5-FLU was over $73 \%$ within 500 min. ${ }^{40}$ Furthermore, in acidic conditions, the 5-FLU released in a biologically active manner and as an anti-metabolite of the pyrimidine analogue. In acidic medium ( $\mathrm{pH}$ 5.2), $-\mathrm{NH}_{2}$ groups in the $\mathrm{CS}$ polymer matrix stayed simply protonated into $-\mathrm{NH}_{3}{ }^{+}$groups, which can weaken hydrogen bonding interactions between the CS polymer which was dissolved in a buffer solution, and released over the diffusion process. ${ }^{41}$ It is well known that chitosan is soluble in water in acidic media $(\mathrm{pH}=2-6)$. At this $\mathrm{pH}$, chitosan swells and its chains undergo deployment due to the electrostatic repulsion of positively charged $-\mathrm{NH}^{3+}$ groups. These results indicated that the release of 5-FLU from the NPs can be measured by changing the $\mathrm{pH}$, which may facilitate its drug delivery and controlled discharge into cancer cells since the microenvironment of the extracellular tissues of tumors and intracellular lysosomes and endosomes are acidic. $^{42-44}$

In additional analysis, for the site-specific drug delivery of $\mathrm{Fe}_{3} \mathrm{O}_{4} @ \mathrm{OA}-\mathrm{CS}-5$-FLU-NP in cancer, the 5-FLU release behavior from $\mathrm{Fe}_{3} \mathrm{O}_{4} @ \mathrm{OA}-\mathrm{CS}-5-\mathrm{FLU}-\mathrm{NPs}$ was carried out at $\mathrm{pH} 5.2$ in the presence of $\mathrm{H}_{2} \mathrm{O}_{2}$. The 5-FLU release rate from $\mathrm{Fe}_{3} \mathrm{O}_{4} @ \mathrm{OA}-\mathrm{CS}-5-\mathrm{FLU}-\mathrm{NP}$ at $\mathrm{pH} 7.4$ was very low, while at $\mathrm{pH} 5.2$, there was a high 

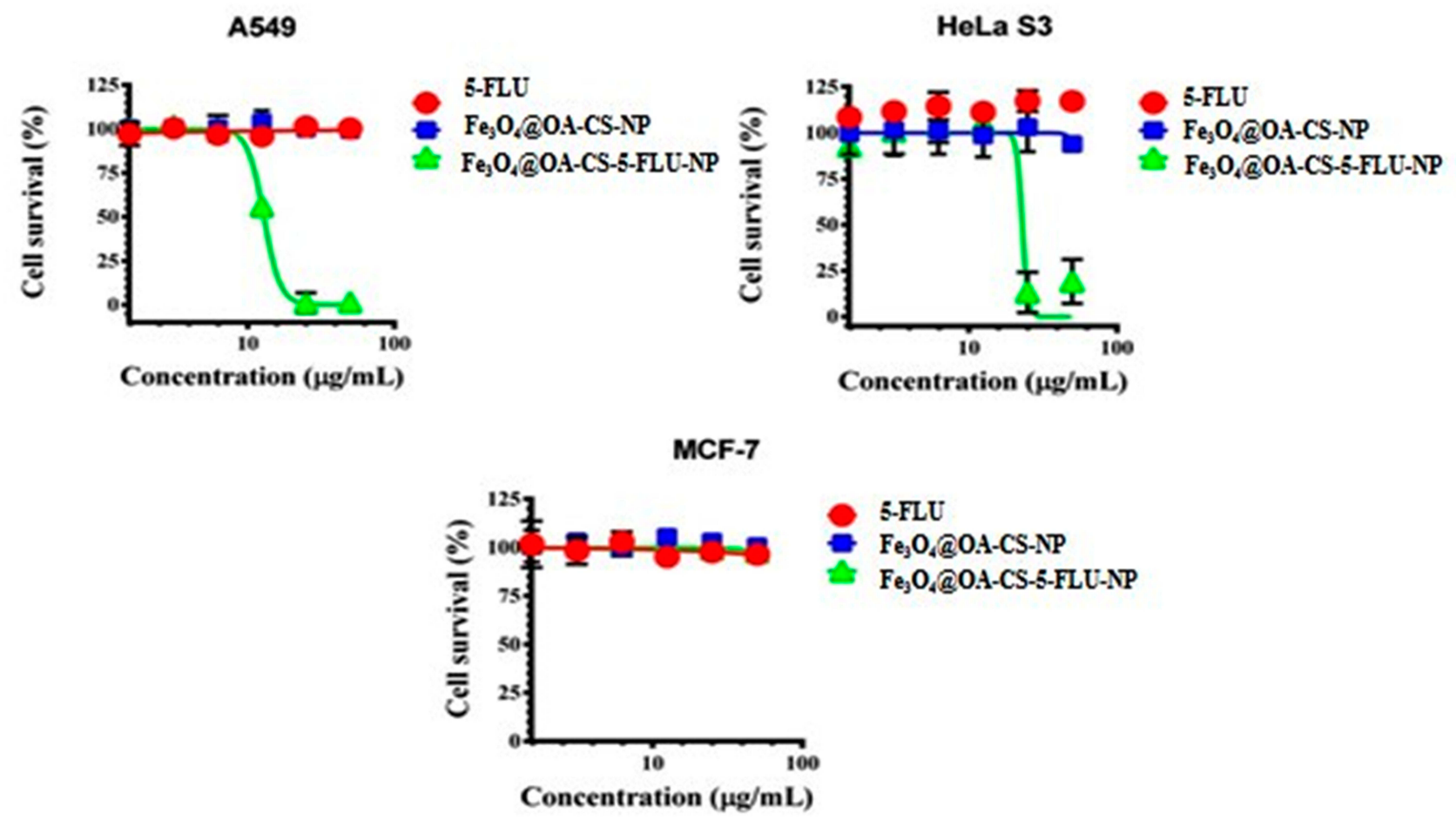

Figure I I Cytotoxic studies of nanoparticles examined by MTT assays against human A549, Hela S3 and MCF-7 cancer cells. The experiments were conducted three times and the data expressed as mean \pm SD of individual and statistical data were analyzed using GraphPad Prism 6 software.

rate of 5-FLU released in a controlled fashion, simplifying the release of 5-FLU in carcinogenic cells as biologically active. The experimental results exposed that the $\mathrm{pH}-$ dependent 5-FLU release from the $\mathrm{Fe}_{3} \mathrm{O}_{4} @ \mathrm{OA}-\mathrm{CS}$ -5-FLU-NPs also led to a high releasing proficiency in the presence of ROS $\left(\mathrm{H}_{2} \mathrm{O}_{2}\right)$. The rate of 5-FLU release in the presence of $\mathrm{H}_{2} \mathrm{O}_{2}$ was higher than in the absence of $\mathrm{H}_{2} \mathrm{O}_{2}$ at $\mathrm{pH}$ 5.2; almost $90 \%$ of the 5-FLU was released after 450 min (Figure 8B), although only $70 \%$ of the 5-FLU was released at pH 5.2 in the absence of $\mathrm{H}_{2} \mathrm{O}_{2}$.

It is assumed that only the CS layer degraded at $\mathrm{pH} 5.2$ which led to the release of 5-FLU, but in the presence of

Table I IC50 Values of the Synthesized NPs Against Human A549, HeLa S3, MCF-7 and IMR-90 Cells

\begin{tabular}{|l|l|l|l|l|}
\hline Complex & $\begin{array}{l}\text { A549 } \\
(\mu \mathrm{g} / \\
\mathrm{mL})\end{array}$ & $\begin{array}{l}\text { HeLa S3 } \\
(\mu \mathrm{g} / \mathrm{mL})\end{array}$ & $\begin{array}{l}\text { MCF-7 } \\
(\mu \mathrm{g} / \mathrm{mL})\end{array}$ & $\begin{array}{l}\text { IMR-90 } \\
(\mu \mathrm{g} / \mathrm{mL})\end{array}$ \\
\hline $5-\mathrm{FLU}$ & $>50$ & $>50$ & $>50$ & $\mathrm{NT}$ \\
$\mathrm{Fe}_{3} \mathrm{O}_{4} @ \mathrm{OA}-$ & $>50$ & $>50$ & $>50$ & $\mathrm{NT}$ \\
$\mathrm{CS}-\mathrm{NP}$ & 12.9 & 23 & $>50$ & $>50$ \\
$\mathrm{Fe}_{3} \mathrm{O}_{4} @ \mathrm{OA}-$ & & & \\
$\mathrm{CS}-5-\mathrm{FLU}-\mathrm{NP}$ & & & \multicolumn{2}{|l}{} \\
\hline
\end{tabular}

Abbreviation: NT, not tested.
$\mathrm{H}_{2} \mathrm{O}_{2}$, the OA layer also degraded (at the same time breaking of bonds amongst the hydrophilic as well as hydrophobic part of OA) which facilitated a high release of 5-FLU from the $\mathrm{Fe}_{3} \mathrm{O}_{4} @ \mathrm{OA}-\mathrm{CS}-5$-FLU-NPs; OA acts as a modifier in nanoparticle synthesis. OA showed good dispersion ability, and which could be ascribed to the great reduction in high surface energy and dipolar attraction of the nanoparticles. ${ }^{45}$ These results clearly exposed that the $\mathrm{Fe}_{3} \mathrm{O}_{4} @ \mathrm{OA}-\mathrm{CS}$ -5-FLU-NP had favorable 5-FLU release in the presence of ROS (Figure 9), and that the $\mathrm{Fe}_{3} \mathrm{O}_{4} @ O A-C S-5-F L U-N P$ are suitable carriers to deliver 5-FLU at targeted cancerous cell sites without worrying about primary release in the circulation. ${ }^{46}$ Also, the 5-FLU releasing efficiency from the $\mathrm{Fe}_{3} \mathrm{O}_{4} @$ OA-CS-5-FLU-NPs increased with an increase of the mixed concentrations of CS. The increase in polymer concentration led to an increase in both particle size and encapsulation efficiency of the prepared NPs. This was attributed to the increased viscosity that helped to enlarge the size and maximize encapsulation efficiency. ${ }^{47}$

The 5-FLU release from the $\mathrm{Fe}_{3} \mathrm{O}_{4} @$ OA-CS-5-FLU$\mathrm{NP}$ at pH $5.2\left(\mathrm{H}_{2} \mathrm{O}_{2}\right.$ in PBS $)$ demonstrated a high amount of 5-FLU released in a controlled manner, as shown in Figure 10. The release of 5-FLU in cancerous cells was also biologically active under acidic conditions. Due to its 


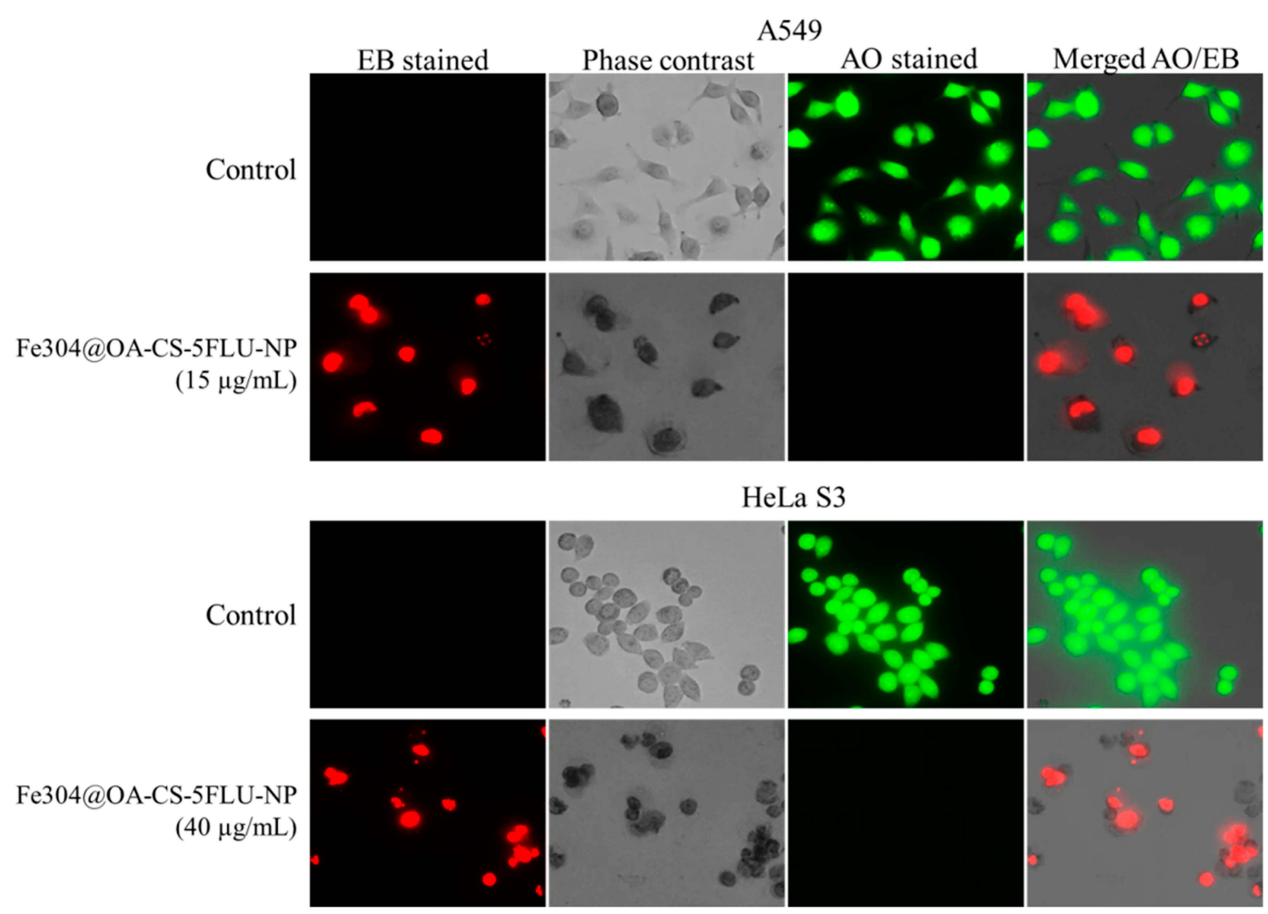

Figure 12 Mode of cell death as analyzed by fluorescence microscopy (Biorevo, BZ-9000, Keyence) using EB and AO after the addition of active Fe $\mathrm{O}_{4} @ \mathrm{OA}-\mathrm{CS}-5-\mathrm{FLU}-\mathrm{NP}$ in A549 and HeLa S3 cells. Red color indicates dead cells and green color indicates live cells tested with 15 and $40 \mu g / m L$ for $24 \mathrm{~h}$ at $37^{\circ} \mathrm{C}$. Scale bar: $50 \mu \mathrm{m}$.

structure, 5-FLU hinders nucleoside metabolism and can be combined into RNA and DNA, leading to cytotoxicity and cell death. Moreover, powerful scavengers of freeradical oxidants result via $\mathrm{H}$-atom donation as well as electron transfer, exerting their antioxidant activity. ${ }^{48-50}$ However, the $\mathrm{Fe}_{3} \mathrm{O}_{4} @ \mathrm{OA}-\mathrm{CS}-5-\mathrm{FLU}-\mathrm{NPs}$ exhibited 5 -FLU release at $\mathrm{pH} \mathrm{5.2,} \mathrm{indicating} \mathrm{the} \mathrm{nature} \mathrm{of} \mathrm{the}$ loaded 5-FLU suggesting that the $\mathrm{Fe}_{3} \mathrm{O}_{4} @ \mathrm{OA}-\mathrm{CS}-5-\mathrm{FLU}-$ NPs are proper carriers to deliver 5-FLU to targeted cancerous cell sites without early release.

\section{In vitro Anticancer Studies}

To further investigate the cell-toxic properties of the nanoparticles, including 5-FLU and $\mathrm{Fe}_{3} \mathrm{O}_{4} @ \mathrm{OA}-\mathrm{CS}-\mathrm{NPs}$ and $\mathrm{Fe}_{3} \mathrm{O}_{4} @$ OA-CS-5-FLU-NPs, to A549, HeLa S3 and MCF-7 cells, MTT assays using different concentrations $(1.5-50 \mu \mathrm{g} / \mathrm{mL})$ for $24 \mathrm{~h}$ at $37^{\circ} \mathrm{C}$ were conducted. As depicted in Figure 11 and Table 1, the viability of the A549, HeLa S3 and MCF-7 cells in the presence of $\mathrm{Fe}_{3} \mathrm{O}_{4}$ (a) OA-CS-5-FLU-NPs displayed higher cytotoxicity against A549 and HeLa S3 cells with IC50 values after $24 \mathrm{~h}$ of 12.9 and $23 \mu \mathrm{g} / \mathrm{mL}$, respectively. In addition, A549, HeLa S3 and MCF-7 cell viability did not change by $\mathrm{Fe}_{3} \mathrm{O}_{4} @ \mathrm{OA}-\mathrm{CS}-\mathrm{NP}$ exposure. Further, toxicity studies on 5-FLU and $\mathrm{Fe}_{3} \mathrm{O}_{4}$ @OA-CS-5-FLU-NP for human normal lung IMR-90 cells were conducted by MTT assays. Remarkably, both 5-FLU and $\mathrm{Fe}_{3} \mathrm{O}_{4} @ \mathrm{OA}-\mathrm{CS}-5-\mathrm{FLU}-\mathrm{NPs}$, did not show toxicity up to $>50 \mu \mathrm{g} / \mathrm{mL}$ for IMR-90 cells. ${ }^{51}$ The $\mathrm{Fe}_{3} \mathrm{O}_{4}$ nanoparticle aggregates of different sizes were characterized for their uptake and toxicity in three different cell lines. While the aggregation did not elicit a unique toxic response, the uptake patterns were different between single and aggregated nanoparticles. There was a decrease in uptake of aggregated nanoparticles by HeLa S3 and A549 cells in comparison to single and monodispersed nanoparticles.

In addition, the cytotoxic study revealed cell morphological modifications and nucleus fragmentation using a costaining process with acridine orange (AO) and ethidium bromide (EB) of A549 and HeLa S3 cells. Here, AO was used as a staining reagent of live cells and $\mathrm{EB}$ was used as an indicator for dead cells. A549 and HeLa S3 cells were examined in the presence of $\mathrm{Fe}_{3} \mathrm{O}_{4} @ \mathrm{OA}-\mathrm{CS}-5$-FLU-NPs (15 and $40 \mu \mathrm{g} / \mathrm{mL}$ ) for $24 \mathrm{~h}$ and pictures were captured with the help of $\mathrm{AO} / \mathrm{EB}$ under fluorescence microscopy. As presented in Figure 12, in the presence of $\mathrm{Fe}_{3} \mathrm{O}_{4} @ \mathrm{OA}-\mathrm{CS}-5-\mathrm{FLU}-\mathrm{NPs}$, cell death of A549 and HeLa S3 cells gradually increased as specified by the red color which co-stained EB. ${ }^{52}$

Moreover, this study further investigated whether the $\mathrm{Fe}_{3} \mathrm{O}_{4} @$ OA-CS-5-FLU-NPs had an ability to control A549 and HeLa S3 cell colonization. As shown in Figure 13, complete inhibition of colony development was demonstrated in the presence of $\mathrm{Fe}_{3} \mathrm{O}_{4} @ \mathrm{OA}-\mathrm{CS}-5$-FLU-NPs 


\section{A}
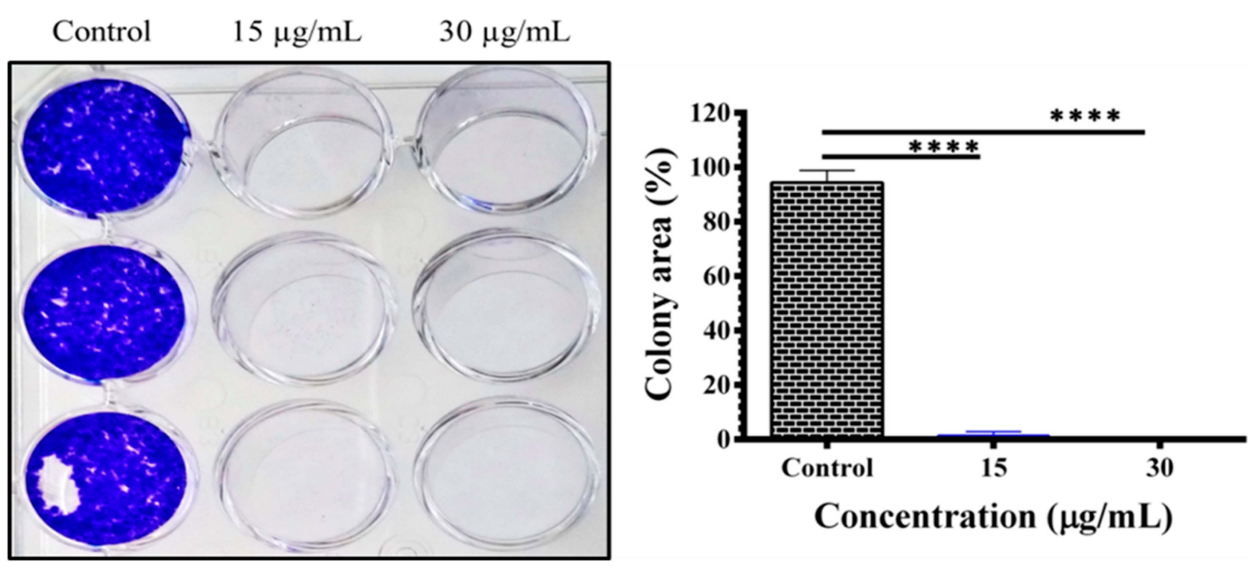

B
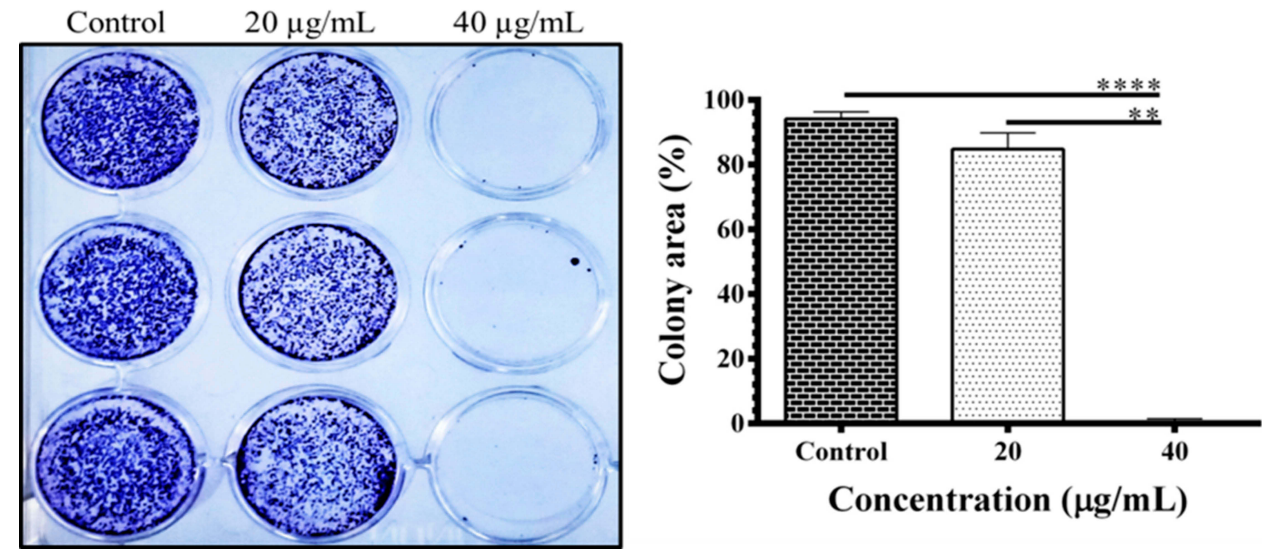

Figure 13 Colony formation in the presence of $\mathrm{Fe}_{3} \mathrm{O}_{4} @ O$ OA-CS-5-FLU-NP examined against A549 and HeLa S3 cells: (A) A549 and (B) HeLa S3 cells. The colony area was calculated by ImageJ software using colony area $($ mean \pm SD). Significance of $* * * * p<0.0001$ and $* * p<0.01$ as compared with the untreated control group.

against $\mathrm{A} 549$ and $\mathrm{HeLa} 33$ cells at 15 and $40 \mu \mathrm{g} / \mathrm{mL}$, respectively. However, $\mathrm{Fe}_{3} \mathrm{O}_{4} @$ OA-CS-5-FLU-NPs did not affect cell colony formation at a lower concentration of $20 \mu \mathrm{g} / \mathrm{mL}$ for the Hela S3 cells. Finally, we conclude here that the $\mathrm{Fe}_{3} \mathrm{O}_{4} @ \mathrm{OA}-\mathrm{CS}-5$-FLU-NPs not only showed cytotoxicity (including morphological changes) but also showed a capability to reduce the colony formation of A549 and HeLa S3 cells. ${ }^{53}$

\section{Conclusion}

In summary, $\mathrm{Fe}_{3} \mathrm{O}_{4} @ \mathrm{OA}-\mathrm{CS}-5$-FLU-NPs were synthesized by an easy and quick in situ loading method. The proposed $\mathrm{Fe}_{3} \mathrm{O}_{4} @ \mathrm{OA}-\mathrm{CS}-5$-FLU-NPs were successfully prepared as well as characterized by several spectroscopic and microscopic studies. They showed significant ROS reactive drug-releasing properties. Further, the $\mathrm{Fe}_{3} \mathrm{O}_{4} @ \mathrm{OA}-\mathrm{CS}$ -5-FLU-NPs showed promising magnetic properties that could be used for magnetic targeted and $\mathrm{pH}$-responsive drug-delivery systems. The $\mathrm{pH}$ triggered drug release of 5-FLU from $\mathrm{Fe}_{3} \mathrm{O}_{4} @ \mathrm{OA}-\mathrm{CS}-5$-FLU-NPs includes the ROS-responsive polymeric nanocarriers under marginally acidic conditions of $\mathrm{pH} 5.2$ and $\mathrm{pH}$ of 7.4. Meanwhile, the MTT assay, fluorescence staining as well as colony formation assay results, revealed that the $\mathrm{Fe}_{3} \mathrm{O}_{4} @$ OA-CS-5-FLUNPs are active and safe for anticancer biomedical applications, and thus should be further studied.

\section{Acknowledgments}

The authors are thankful to the Department of Science and Technology and Science and Engineering Research Board (DST-SERB, Grant No. SB/FT/CS-130/2012, the Government of India, New Delhi) for funding this work. The authors greatly acknowledge the Chikkanna Government Arts College, Tirupur and the Mohamed Sathak Engineering College, Kilakkarai for providing lab and instrumentation facilities. 


\section{Disclosure}

The authors have no conflicts of interest to declare.

\section{References}

1. Wong HL, Bendayan R, Rauth AM, Li Y, Wu XY. Chemotherapy with anticancer drugs encapsulated in solid lipid nanoparticles. Advan Drug Deliv Rev. 2007;59(6):491-504. doi:10.1016/j.addr.2007.04.008

2. Durán JDG, Arias JL, Gallardo V, Delgado AV. Magnetic colloids as drug vehicles. J Pharm Sci. 2008;97(8):2948-2983. doi:10.1002/jps. 21249

3. Zhang N, Yin Y, Xu SJ, Chen WS. 5-fluorouracil: mechanisms of resistance and reversal strategies. Molecules. 2008;13(8):1551-1569. doi:10.3390/molecules 13081551

4. Arias JL, Ruiz MA, López-Viota M, Delgado AV. Poly(alkylcyanoacrylate) colloidal particles as vehicles for antitumour drug delivery: a comparative study. Colloids Surf B Biointerfaces. 2008;62(1):64-70. doi:10.1016/j.colsurfb.2007.09.018

5. Zhu K, Ye T, Liu J, et al. Nanogels fabricated by lysozyme and sodium carboxymethyl cellulose for 5-fluorouracil controlled release. Int J Pharm. 2013;441(1-2):721-727. doi:10.1016/j.jpharm.2012.10.022.

6. Qi D, Lu J, Deng C, Zhang XJ. Magnetically responsive Fe3O4@C@SnO 2 core-shell microspheres: synthesis, characterization and application in phosphoproteomics. Phys Chem C. 2009;113 (36):15854-15861. doi:10.1021/jp902959d

7. Liu Y, Wang Y, Zhou S, et al. Controllable synthesis of hierarchical porous $\mathrm{Fe}_{3} \mathrm{O}_{4}$ particles mediated by poly(diallyldimethylammonium chloride) and their application in arsenic removal. ACS Appl Mater Interfaces. 2013;5(23):12449-12459.

8. Spanakis M, Bouropoulos N, Theodoropoulos D, Sygellou L, Ewart S, Moschovi AM. Inclusion of new 5-fluorouracil amphiphilic derivatives in liposome formulation for cancer treatment. $J$ Med Chem Commun. 2015;6(9):1639-1642.

9. Mornet S, Portier J, Duguet E. A method for synthesis and functionalization of ultrasmall superparamagnetic covalent carriers based on maghemite and dextran. J Magn Magn Mater. 2005;293(1):127-134. doi:10.1016/j.jmmm.2005.01.053

10. Spanova A, Horak D, Soudkova E, Rittich B. Magnetic hydrophilic methacrylate-based polymer microspheres designed for polymerase chain reactions applications. J Chromatogr B. 2004;800(1-2):27-32. doi:10.1016/j.jchromb.2003.09.010

11. Omi S, Kanetaka A, Shimamori Y, Supsakulchai A, Nagai M, Ma GH. Magnetite $\left(\mathrm{Fe}_{3} \mathrm{O}_{4}\right)$ microcapsules prepared using a glass membrane and solvent removal. J Microencapsul. 2001;18(6):749-765.

12. Caruso F, Susha AS, Giersig M, Mohwald H. Magnetic core-shell particles preparation of magnetite multilayers on polymer latex microspheres. Adv Mater. 1999;11(11):950-953. doi:10.1002/(SICI) 1521-4095(199908)11:11<950::AID-ADMA950>3.0.CO;2-T

13. Liu ZM, Liu YL, Yang HF, Yang Y, Shen GL, Yu RQ. A phenol biosensor based on immobilizing tyrosinase to modified core-shell magnetic nanoparticles supported at a carbon paste electrode. Anal Chim Acta. 2005;533(11):3-9.

14. Chatterjee J, Haik Y, Chen CJ. Synthesis and characterization of heat-stabilized albumin magnetic microspheres. Colloid Polym Sci. 2001;279(11):1073-1081. doi:10.1007/s003960100523

15. Levy L, Sahoo Y, Kim KS, Bergey EJ, Prasad PN. Nanochemistry: synthesis and characterization of multifunctional nanoclinics for biological applications. Chem Mater. 2002;14(9):3715-3721. doi:10.1021/cm0 203013

16. Shahani K, Panyam J. Highly loaded sustained-release microparticles of curcumin for chemoprevention. $J$ Pharm Sci. 2011;100 (7):2599-2609. doi:10.1002/jps.22475

17. Gupta AK, Gupta M. Synthesis and surface engineering of iron oxide nanoparticles for biomedical applications. Biomaterials. 2005;26 (18):3995-4021. doi:10.1016/j.biomaterials.2004.10.012
18. Zhang XY, Wang LXJ. Effects of surface modification on the properties of magnetic nanoparticles/PLA composite drug carriers and in vitro controlled release study. Colloid Surf A-Physicochem Eng. 2013;431(2013):80-86. doi:10.1016/j.colsurfa.2013.04.021

19. Zhang XY, Wang LXJ, Wang J. Development and characterization of size controlled polymeric microcapsules loaded with super paramagnetic nanoparticles. Polym Compos. 2013;34(4):443-449. doi:10.1002/pc.2 2429

20. Unsoy G, Yalcin S, Khodadust R, Gunduz G, Gunduz U. Synthesis optimization and characterization of chitosan coated iron oxide nanoparticles produced for biomedical applications. J Nanopart Res. 2012;14(11):1-13.

21. Li FX, Li XI, Li B. Preparation of magnetic polylactic acid microspheres and investigation of its releasing property for loading curcumin. J Magn Magn Mater. 2011;323(22):2770-2775. doi:10.10 16/j.jmmm.2011.05.045

22. Wei ZJ, Wang CY, Liu H, Zou SW, Tong Z. Systematic studies of pickering emulsions stabilized by uniform-sized PLGA particles: preparation and stabilization mechanism. Colloids Surf B. 2012;91(2012):97-105. doi:10.1016/j.colsurfb.2011.10. 044

23. Liu X, Kaminski MD, Chen H, Torno M, Taylor LA, Rosengart J. Synthesis and characterization of highly-magnetic biodegradable poly (d,l-lactide-co-glycolide) nanospheres. J Control Release. 2007;119(1):52-58. doi:10.1016/j.jconrel.2006.11.031

24. Xu A, Dou HJ, Shi WB, et al. "Two-in-one" fabrication of Fe3O4/ MePEG-PLA composite nanocapsules as a potential ultrasonic/MRI dual contrast agent. Langmuir. 2011;27(19):12134-12142. doi:10.1021/ la202096x

25. Mu B, Zhong W, Dong Y, Du PC, Liu P. Encapsulation of drug microparticles with self-assembled $\mathrm{Fe}_{3} \mathrm{O}_{4}$ /alginate hybrid multilayers for targeted controlled release. J Biomed Mater Res B. 2012;100B (3):825-831. doi: $10.1002 / \mathrm{jbm} . b .32646$

26. Arias JL, Ruiz M, Gallardo V, Delgado AV. Tegafur loading and release properties of magnetite/poly (alkylcyanoacrylate) (core/ shell) nanoparticles. J Control Release. 2008;125(1):50-58. doi:10.10 16/j.jconrel.2007.09.008

27. Zhou L, He B, Zhang F. Facile one-pot synthesis of iron oxide nanoparticles cross-linked magnetic poly(vinyl alcohol) gel beads for drug delivery. ACS Appl Mater Interfaces. 2012;4(1):192-199. doi:10.1021/am201649b

28. Khosroshahi ME, Ghazanfari L. Preparation and rheological studies of uncoated and PVA-coated magnetite nanofluid. J Magn Magn Mater. 2012;324(24):4143-4146. doi:10.1016/j.jmmm.20 12.07.025

29. McConville P, Pope JM. A comparison of water binding and mobility in contact lens hydrogels from NMR measurements of the water self-diffusion coefficient. Polymer. 2000;41(26):9081-9088. doi:10. 1016/S0032-3861(00)00295-0

30. Latorre A, Couleaud P, Aires A, Cortajarena AL, Somoza Á. Multifunctionalization of magnetic nanoparticles for controlled drug release: a general approach. Eur J Med Chem. 2014;82(2014): 355-362. doi:10.1016/j.ejmech.2014.05.078

31. Pham XN, Nguyen TP, Pham TN, Tran TTN, Tran TVT. Synthesis and characterization of chitosan-coated magnetite nanoparticles and their application in curcumin drug delivery. Adv Nat SciNanosci Nanotech. 2016;7(4):045010. doi:10.1088/2043-6262/7/4/ 045010

32. Dilnawaz F, Singh A, Mohanty C, Sahoo SK. Dual drug loaded superparamagnetic iron oxide nanoparticles for targeted cancer therapy. Biomaterials. 2010;31(13):3694-3706. doi:10.1016/j.biomaterials.20 10.01.057

33. Bani D, Bencini A, Bergonzi MC, et al. Enhanced intra-cutaneous delivery of a Mn-containing antioxidant drug by high frequency ultrasounds. J Pharmaceut Biomed Anal. 2015;106(2015):197-203. doi:10.1016/j.jpba.2014.11.021 
34. Li P, Wanga Y, Pengb Z, Shea F, Konga L. Development of chitosan nanoparticles as drug delivery systems for 5-fluorouracil and leucovorin blends. Carbohydr Polym. 2011;85(3):698-704. doi:10.1016/j. carbpol.2011.03.045

35. Zhang LY, Zhu XJ, Sun HW, Chi GR, Xu JX, Sun YI. Control synthesis of magnetic Fe3O4-chitosan nanoparticles under UV irradiation in aqueous system. Curr Appl Phys. 2010;10(3):828-833. doi:10.1016/j.cap.2009.10.002

36. Sekhar EC, Rao KK, Raju, RR. Chitosan/guargum-g-acrylamide semi IPN microspheres for controlled release studies of 5-Fluorouracil. J Appl Pharm Sci. 2011;1(8):199-204.

37. Nivethaa EAK, Dhanavel S, Narayanan V, Vasu CA, Stephen, A. An in vitro cytotoxicity study of 5-fluorouracil encapsulated chitosan/ gold nanocomposites towards MCF-7 cells. RSC Adv. 2015;5 (2):1024-1032. doi:10.1039/C4RA11615A

38. Bhatt AS, Bhat DK, Santosh MS. Electrical and magnetic properties of chitosan-magnetite nanocomposites. Physica B Condens Matter. 2010;405(8):2078-2082. doi:10.1016/j.physb.2010.01.106

39. Liu J, Che R, Chen H. Microwave absorption enhancement of multifunctional composite microspheres with spinel $\mathrm{Fe}_{3} \mathrm{O}_{4}$ cores and anatase $\mathrm{TiO}_{2}$ shells. Small. 2012;8(8):1214-1221. doi:10.1002/smll.201102245

40. Samad AA, Bakkour Y, Fanny C, Omar FE, Coudane J, Nottelet B. From nanospheres to micelles: simple control of PCL-g-PEG copolymers' amphiphilicity through thiol-ynephotografting. Polym Chem. 2015;6(28):5093-5102. doi:10.1039/C5PY00391A

41. Pylypchuk IV, Kołodyńska D, Kozioł M, Gorbyk PP. Gd-DTPA adsorption on chitosan/magnetite nanocomposites. Nanoscale Res Lett. 2016;11(1):168. doi:10.1186/s11671-016-1363-3

42. Chopra D, Ray L, Dwivedi A, et al. Photoprotective efficiency of PLGA-curcumin nanoparticles versus curcumin through the involvement of ERK/AKT pathway under ambient UV-R exposure in HaCaT cell line. Biomaterials. 2016;84(2016):25-41. doi:10.1016/j.biomaterials.2016.01. 018

43. Chen H, Zhang W, Zhu G, Xie J, Chen X. Rethinking cancer nanotheranostics. Nat Rev Mater. 2017;2(7):17024. doi:10.1038/ natrevmats.2017.24
44. Jo SD, Ku SH, Won YY, Kim SH, Kwon IC. Targeted nanotheranostics for future personalized medicine: recent progress in cancer therapy. Theranostics. 2016;6(9):1362-1377. doi:10.7150/thno.15335

45. Ayyanaar S, Kesavan MP, Palpandi Raja R, Rajagopal G, Rajagopal G, Rajagopal G. Reactive oxygen species (ROS)-responsive microspheres for targeted drug delivery of camptothecin. J Drug Deliv Sci Tec. 2019;52(2019):722-729. doi:10.1016/j.jddst.2019.05.036

46. Muthu MS, Leong DT, Mei L, Feng SS. Nanotheranostics-application and further development of nanomedicine strategies for advanced theranostics. Theranostics. 2014;4(6):660-677. doi:10.7150/thno.8698

47. Aldawsari HM. Fluconazole nano-particles loaded gel for improved efficacy in treatment of oral candidiasis. Pharmacology. 2019;15 (3):436-440.

48. Dharmaraja AT. Role of reactive oxygen species (ROS) in therapeutics and drug resistance in cancer and bacteria. J Med Chem. 2017;60 (8):3221-3240. doi:10.1021/acs.jmedchem.6b01243

49. Jeschek D, Lhota G, Wallner J, Vorauer-Uhl K. A versatile, quantitative analytical method for pharmaceutical relevant lipids in drug delivery systems. J Pharmaceut Biomed Anal. 2016;11:37-44.

50. Peng Z, Yang X, Qin J. Glyoxalase-1 overexpression reverses defective proangiogenic function of diabetic adipose-derived stem cells in streptozotocin-induced diabetic mice model of critical limb ischemia. Stem Cells Transl Med. 2017;6(1):261-271. doi:10.5966/sctm.2015-0380

51. Denu RA, Hematti P. Effects of oxidative stress on mesenchymal stem cell biology. Oxid Med Cell Longev. 2016;2016:2989076.

52. Sun $\mathrm{Y}, \mathrm{Hu} \mathrm{X}, \mathrm{Hu} \mathrm{G}, \mathrm{Xu} \mathrm{C}$, Jiang H. Curcumin attenuates hydrogen peroxide-induced premature senescence via the activation of SIRT1 in human umbilical vein endothelial cells. Biol Pharm Bull. 2015;38 (8):1134-1141. doi:10.1248/bpb.b15-00012

53. Kukongviriyapan U, Apaijit K, Kukongviriyapan V. Oxidative stress and cardiovascular dysfunction associated with cadmium exposure: beneficial effects of curcumin and tetrahydrocurcumin. Tohoku J Exp Med. 2016;239(1):25-38. doi:10.1620/tjem.239.25
International Journal of Nanomedicine

\section{Publish your work in this journal}

The International Journal of Nanomedicine is an international, peerreviewed journal focusing on the application of nanotechnology in diagnostics, therapeutics, and drug delivery systems throughout the biomedical field. This journal is indexed on PubMed Central, MedLine, CAS, SciSearch ${ }^{\mathbb{}}$, Current Contents ${ }^{\mathbb{R}} /$ Clinical Medicine, $^{-}$
Journal Citation Reports/Science Edition, EMBase, Scopus and the Elsevier Bibliographic databases. The manuscript management system is completely online and includes a very quick and fair peer-review system, which is all easy to use. Visit http://www.dovepress.com/ testimonials.php to read real quotes from published authors 